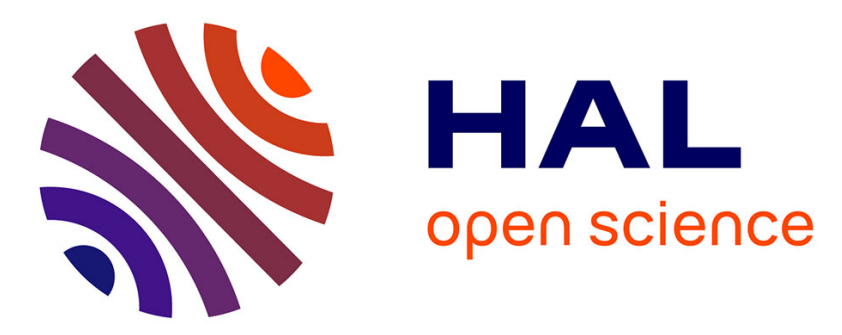

\title{
Two-stage modeling of Strombolian-type eruptions and quantification of the model parameters: Insight from the seismic and acoustic signals
}

\author{
Vyacheslav M Zobin, Jean Battaglia, William Melson, Yasuaki Sudo
}

\section{- To cite this version:}

Vyacheslav M Zobin, Jean Battaglia, William Melson, Yasuaki Sudo. Two-stage modeling of Strombolian-type eruptions and quantification of the model parameters: Insight from the seismic and acoustic signals. Physics of the Earth and Planetary Interiors, 2019, 297, pp.106318. 10.1016/j.pepi.2019.106318 . hal-03065557

\section{HAL Id: hal-03065557 https://hal.science/hal-03065557}

Submitted on 14 Dec 2020

HAL is a multi-disciplinary open access archive for the deposit and dissemination of scientific research documents, whether they are published or not. The documents may come from teaching and research institutions in France or abroad, or from public or private research centers.
L'archive ouverte pluridisciplinaire HAL, est destinée au dépôt et à la diffusion de documents scientifiques de niveau recherche, publiés ou non, émanant des établissements d'enseignement et de recherche français ou étrangers, des laboratoires publics ou privés. 
2 Two-stage modeling of Strombolian-type eruptions and quantification of the model parameters: Insight from the seismic and acoustic signals

4

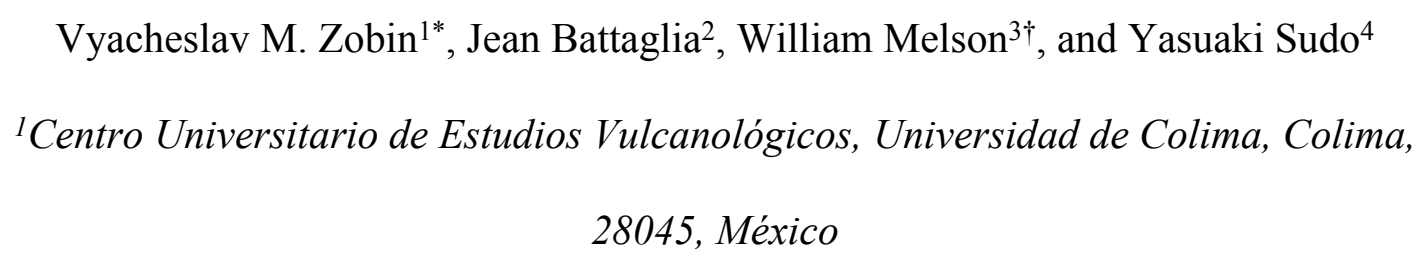

\begin{abstract}
The seismic signals of majority Strombolian explosions show a two-phase structure that may be the result of a two-stage explosive eruption. We quantify the parameters of two proposed stages of Strombolian eruptions at volcanoes Arenal, Aso and Yasur using 193 seismic records and 18 acoustic signals and considering that the first stage of eruption represents the seismically active process of the gas slug expansion and ascent (GSEA) in the conduit and the second stage is associated with the gas slug burst at the surface. It is shown that the radiated seismic energy of Strombolian explosions at volcanoes is strongly dependent on the seismic energy radiated during GSEA. The seismic energy of explosions is correlated also with the duration of GSEA process in the interval of durations between 1.3 and 3.7 s. For shorter GSEA durations, the correlation is absent.
\end{abstract}

\footnotetext{
* Corresponding autor. E-mail vzobin@ucol.mx

$\uparrow$ Deceased
} 
The acoustic energy of explosions is characterized by inverse dependence on the durations of GSEA. These results demonstrate the influence of the GSEA process on the surface manifestations of Strombolian explosions.

Keywords: volcano; Strombolian explosion; seismic signal; acoustic signal; gas slug; plug.

\section{Introduction}

Strombolian-type mild explosive eruptions, named after the Italian volcano Stromboli (Aeolian Islands) (Fig. 1) are characteristic for basaltic and andesito-basaltic volcanoes. They are short (seconds to minutes), discrete, and produce eruptive columns or lava fountains; they occur at quasi-regular intervals producing 3-5 explosions / hour with the eruption columns of tens or hundreds of meters in height (Vergniolle and Mangan, 2000). Low viscosity silica-poor magmas of this type of volcanoes allow the efficient segregation of the ex-solved gas from the magma and its independent rise (Harris and Ripepe, 2007). A study of the long-time recorded seismic signals of Stromboli and Erebus volcanoes allowed determining the Poissonian inter-time distribution function of the Strombolian explosion-quakes (Bottiglieri et al., 2005; De Lauro et al., 2009). The explosions are supposed to be driven by large gas bubbles, or slug (Taylor bubble), rising up the conduit and bursting at the surface (Del Bello et al., 2012; Pering et al., 2017).

A slug of gas represents a particular type of gas bubble flowing through a liquidfilled pipe. It is characterized by having a width comparable to that of the pipe and a round- or bullet-shaped head and a cylindrical body. Gas overpressure within the bursting slug governs explosion dynamics and vigor. At burst, a typical Strombolian 
49 slug (with a volume of $100-1000 \mathrm{~m}^{3}$ ) has an internal gas pressure of 1-5 bars and a length of 13-120 m (Del Bello et al., 2012; Taddeucci et al., 2015).

The slugs may be formed by coalescence of smaller bubbles. The "collapsing foam model" (Jaupart and Vergniolle, 1988) proposes this coalescence due to accumulation at geometrical discontinuities. The "rise speed model" (Parfitt and Wilson, 1995) supposes higher bubbles velocities in respect to the magma that may lead to transition from bubbly to slug flow. Both models demonstrate that the process of Strombolian eruption may be represented as the gas slug expansion and ascent within the conduit with following burst of the gas slug. The laboratory experiments and field studies (e.g., Lautze and Houghton, 2007; Gurioli et al., 2014) showed that the process of gas slugs ascent and burst develops through the rheologically stratified magma within a conduit. There was indicated the existence of an evolved high-viscosity magma region at the top of the conduit, acting as a plug sealing the vent (Capponi et al., 2016).

Strombolian explosions are usually accompanied with seismic and acoustic signals (Vergniolle and Brandeis, 1994; Chouet et al., 1997; Johnson, 2003). The mentioned above modeling of Strombolian process allows to associate the appearance of these signals with the development of the gas slug activity in the conduit and its burst at the surface. Fig. 2A shows the seismic and acoustic signals recorded during the 1992 activity at Stromboli volcano at a distance of $150 \mathrm{~m}$ from the crater (Chouet et al., 1997). A short-period seismogram of Strombolian explosion (vertical component of ground velocity) consists of an initial (IP) low-frequency phase with dominant frequency near $2 \mathrm{~Hz}$, and the main phase $(M P)$ of higher-frequency up to $10 \mathrm{~Hz}$ starting $1.1 \mathrm{~s}$ after the onset of the event. The onset of the higher-frequency signal was noted to coincide with the visually observed onset of the eruptive jet, while no visible surface activity could be linked with the precursory low-frequency onset. The high-frequency 
acoustic signal, shown in the same Fig. 2A, was characterized by an impulsive arrival at about $2 \mathrm{~s}$ after the initial onset of the seismic signal.

In this article we apply the seismic and acoustic signals, produced by Strombolian explosive events at Arenal volcano (Costa Rica), and the seismic signals, recorded at Aso (Japan) and Yasur (Vanuatu) volcanoes, to quantify the parameters of Strombolian eruptions. The locations of these three volcanoes are shown in Fig. 1.

Quantification of eruption parameters is performed in a frame of a conceptual model, considering the expansion and ascent of gas slug (GSEA) within the rheologically stratified conduit with the high-viscosity magma region (plug) at the top of the conduit as the first stage of Strombolian eruption and the burst at the surface as the second stage. The following parameters, derived from the seismic and the acoustic phases, are discussed: the duration of seismically active process of the gas-slug expansion and its ascent to the surface; the seismic energy radiated during the two stages of explosion; and the acoustic energy of explosion. The empirical scaling relationships of the mentioned parameters, calculated for three volcanoes, are discussed. During the discussions, the decisive role of the process of GSEA on the eruption manifestations is shown.

\section{Eruptive activity of studied volcanoes and instrumentation}

\subsection{Arenal volcano, Costa Rica}

\subsubsection{Eruptive activity}

Arenal volcano belongs to the Arenal-Chato volcanic system in north-western Costa Rica (Fig. 1, Fig. 3B). It is a steep-sided, 1,657-m-high strato-volcano, that has a basal diameter of around $8 \mathrm{~km}$. Arenal is a young volcano, predominantly $<4,000$ years old, whose products are mainly basaltic andesite in composition (Borgia et al., 1988; Cole et 
al., 2005). The volcano re-awakened on 29 July 1968 after 46 years of dormancy with the VEI 3 explosive eruption (VEI is the Volcanic Explosivity Index; Newhall and Self, 1982) (http://volcano.si.edu/volcano.cfm?vn=345033; Alvarado Induni, 2000).

Three new craters, $A, B$ and $C$, opened on the western flank of the volcano during the 1968 eruption (Fig. 3B). Beginning from the early 1970s, the activity migrated to crater $C$. The volcano entered Strombolian phase in 1984 (Alvarado and Soto, 2002). Since the mid-1980s and till the end of eruption cycle in December 2010, similar patterns of spasmodic Strombolian explosions that ejected incandescent fragments and propel ash-laden columns to heights of $0.5-2 \mathrm{~km}$ (Fig. 3A) took place from the crater $C$ (http://volcano.si.edu/volcano.cfm?vn=345033). The monthly numbers of explosions, recorded during 1989-1994, reached from 400 to 2000 events (Alvarado et al., 1997).

\subsubsection{Monitoring network}

The simultaneous recording of seismic and acoustic signals was performed at Arenal volcano by W. Melson (Smithsonian Institution, USA) during April and July 1991. The seismic/acoustic station, $S+A$, was installed on the southern slope of the volcano at a distance of $2.7 \mathrm{~km}$ from the active crater $C$ (Fig. 3B). A Cole-Palmer analog-digital fullsize expansion card allowed recording of four direct channels (three-component seismic velocity signals and acoustic signal) with precision of \pm 0.1 millivolts. The seismic channels were directly connected to the short-period $(T=1 \mathrm{~Hz})$ Mark Products L-4-3D geophone. The acoustic waves that accompanied the volcanic explosion were recorded by the 33-2050 Sound level meter.

\subsection{Aso volcano, Japan}

2.2.1. Eruptive activity of Aso volcano 
Aso volcano is situated in the centre of Kyushu Island, Japan and comprises the Aso caldera and post-caldera central cones (Fig. 1, Fig. 4B). The only active cone, Nakadake, representing the 1506-meters-high peak of Aso volcano, is composed of basaltic andesite to basalt. Its crater includes seven craterlets aligned N-S. During active periods, its northernmost craterlet No. 1 (Fig. 4B) is characterized by Strombolian explosions and phreatic or phreatomagmatic explosions (Nat. Cat. Active Volc. Jap., JMA,

http://www.data.jma.go.jp/svd/vois/data/tokyo/STOCK/souran_eng/souran.htm\#kyusyu okinawa).

The recent eruption activity at Aso volcano, within the Nakadake craterlet No. 1, began on 25 November 2014 with a Strombolian explosion, causing ashfall and glowing emissions. Strombolian ash eruptions (Fig. 4A) continued until the mid-May 2015 (BGVN, 2015).

\subsubsection{Monitoring network}

This study is based on the seismic information obtained from the crater-rim seismic station KAF situated at a distance of about $150 \mathrm{~m} \mathrm{~W}$ from the active vent (Fig. 4B). This station, belonging to the Aso Volcano Laboratory of Kyoto University and the Aso Volcano Museum, was equipped with a short-period $(\mathrm{T}=1 \mathrm{~s})$ vertical velocity sensor; the analogue signals were digitized with a 16 bit $\mathrm{A} / \mathrm{D}$ (analogue to digital) converter.

\subsection{Yasur volcano}

2.3.1. Eruptive activity of Yasur volcano

Yasur is a basaltic scoria cone located on the south-western part of Tanna Island, in the south of Vanuatu archipelago (Fig. 1). It is a relatively small volcano (361 m a.s.1. high, 
$1500 \mathrm{~m}$ diameter). Present activity at Yasur cinder cone consists of Strombolian activity (Fig. 5A), produced from three small active craters (denoted as A, B and C in Fig. 5B) within a larger 400-m diameter crater. In August 2008, when the temporary seismic deployment, whose data we use in this article, was carried at Yasur, all three craters were active (Kremers et al., 2012; Battaglia et al., 2016a).

\subsubsection{Monitoring network}

A temporary seismic network was installed at Yasur volcano in 2008 (Battaglia et al., 2016a). In our study we use the seismic signals recorded by the seismic station YO5 (velocity, vertical component) installed at a distance of $650 \mathrm{~m}$ from the crater (Fig. 5B). This station was chosen because of its proximity to the summit allowing good signal to noise ratios for smaller events. The station was equipped with Agecodagis CDJZ shortperiod sensor with a $2 \mathrm{~Hz}$ natural frequency connected to an Osiris digitizer.

\section{Data used in this study}

Strombolian activity may generate a great variety of seismic signals as was showed, for example, by Battaglia et al. (2016a) and Spina et al. (2015) during their study of the 2008 Strombolian explosions at Yasur volcano. They noted that a large portion of the recorded signals formed families of similar events.

For our analysis of Strombolian explosions, the seismic signals with a twophase pattern were selected. The selection was performed manually based on the following criteria: two-phase signals and a good signal-noise ratio. The example of waveform, which was selected for analysis, is a waveform recorded during Strombolian activity at Aso volcano (Fig. 2B). It is similar to the waveform of Strombolian explosion at Stromboli volcano shown in Fig. 2A, and a good signal-noise ratio allows 
us to pick the arrivals of initial and main phases with precision of $\pm 0.1 \mathrm{~s}$. At the same time, the waveform, shown in Fig. 2C, which was recorded during Strombolian activity at Yasur volcano, has more complicated structure, with no similarity with the waveform of Fig. 2A. These waveforms were not included in the database for analysis.

\subsection{Arenal volcano}

For this study, we have the signals associated with nineteen explosions. Fig. 6 shows the simultaneous records of the seismic and acoustic signals associated with two Strombolian explosions, occurring in April and July, 1991, and their Fourier spectra. In the seismic signals (velocity, vertical components), the waveforms represent the twophase records (Fig. 6, A and D). The initial phases $\left(I P, t_{2}-t_{1}\right)$ are relatively lowamplitude signals. The main phases $\left(M P, t_{3}-t_{2}\right)$ represent the spindle-type higheramplitude signals. The relation between the frequency content of two phases (Fig. 6, C and F) is not constant, the initial phases may be of lower (Fig. 6C) or higher (Fig. 6F) frequency than the main phases.

Acoustic signals arrived just after the main seismic phases (Fig. 6, B and E). The amplitudes of acoustic signals of the explosions spanned over two orders of magnitude. Depending on their intensity, they may be seen (Fig. 6A) or not (Fig. 6D) on the seismic signals.

\section{2. Aso volcano}

Totally 100 seismic signals, recorded during November 2014 to February 2015, were selected for analysis. The seismic signals are similar having a two-phase structure (Fig. 7, A, C, and E). The stack of ten signals and corresponding Fourier spectra, presented in (Zobin and Sudo, 2017), demonstrated that the waveforms have a good inter-cluster 
correlation. The initial phases $\left(I P, t_{2}-t_{1}\right)$, are of lower frequency and smaller amplitude compared with the following higher-frequency, higher-amplitude main $\left(M P, t_{3}-t_{2}\right)$ phases, marked by two arrows, labeled with (Fig. 7, B, D, and F). No high-frequency signals of acoustic waves were seen on the seismograms.

\section{3. Yasur volcano}

A total of 74 well-quality two-phase seismic signals, recorded at station YO5 during 8 August 2008, were used for analysis. They were selected from about 2000 small events that were recorded this day (Battaglia et al., 2016b). Fig. 8 shows the characteristic twophase seismic signals (Fig. 8, A, C, and E) and their Fourier spectra (Fig. 8, B, D, and F). These signals are characterized by the initial (IP, $\left.t_{2}-t_{1}\right)$ low-frequency and lowamplitude phases (indicated between labels) and following higher-amplitude and higher-frequency main phases $(M P)$ that are recorded after the label $t_{2}$. The acoustic wave onsets are seen at only about of 50\% of selected seismic records (Fig. 8, A and C, with air waves; Fig. 8E, without air wave).

\section{The conceptual model of two-stage process of Strombolian explosions}

The analysis of seismic and acoustic signals of Strombolian explosions is based on a conceptual model of two-stage process of Strombolian explosions (Fig. 9A). The following elements of the model are indicated:

1. Initial aseismic gas slug rise;

2. Seismically and acoustically active rapid gas expansion creating a gas overpressure with the consequent rapid ascent of the gas slug towards the surface; 
3. Partial collection of the gas slugs within the degassed, crystalline magma region characterized by increased viscosity, or plug, at the top of the conduit with following gas slug ascent to the surface;

4. Burst of the gas slugs ascending along the conduit or liberating from the plug. The first stage includes the elements 2 and 3 of the model. The second stage represents a burst of gas slug at the surface.

Fig. 9B illustrates the occurrence of two seismic phases corresponding to two stages of the eruption. The seismic signal of $I P$ is proposed to be generated during stage 1 when the over-pressurred gas slug within the volcanic conduit begins to be seismically active, supposedly due to the start of rapid expansion of gas in the slug and the consequent rapid acceleration of the gas slug towards the surface. It may be generated also by the ascent of the gas slugs collected within the plug. The seismic signal of $M P$ is supposed to be produced during the explosion occurring at the surface due to the gas slug burst (stage 2).

The proposed conceptual model of two-stage seismically active Strombolian process is constrained by the following parameters derived from the two seismic and the acoustic phases:

1. The duration of seismically active process of gas expansion and slug ascent, $G S E A$, in the conduit or from the plug at the top of the conduit, corresponding to the duration, $t_{2}-t_{1}$, of the initial seismic phase IP (Fig. 9B);

2. Seismic energy, $E_{s}$, radiated during the two stages of Strombolian explosive eruption, of the initial stage of seismically active gas-slug ascent and expansion in the conduit, $E_{S I S t}$, and of the main stage of explosion, $E_{S M S t}$;

3. Acoustic energy of explosion, $E_{a}$. 
These parameters will be quantified and their empirical relationships in the terms mentioned above will be discussed. The significance of scaling relationships between parameters will be checked at $99 \%$ confidence level.

\section{Data processing}

The quantification of parameters of two stages of Strombolian type eruptions, based on the seismic and acoustic records of events, is performed in a frame of a conceptual model described above.

\subsection{Measurement of the duration of the initial seismic phase}

As Fig. 9B shows, the duration of the initial phase, corresponding to GSEA, is measured as the interval between the time of arrival of the two phases of IP and $M P, t_{2}-t_{1}$.

\section{2. Calculation of the seismic energy radiated during the two stages}

The seismic energy, $E_{s}$, radiated during each of two stages of Strombolian explosion, was estimated assuming a point-source and considering the medium as isotropic and homogeneous. It was assumed also that surface Rayleigh waves dominate the seismic signal of volcanic explosions (Tameguri et al., 2002; Zobin et al., 2006; Nakamuchi et al., 2017). The following equation was used to calculate the seismic energy radiated during each of the two stages (Hibert et al., 2017):

$$
E_{s}=2 \pi r \rho h c e^{\alpha r} \int_{T_{1}}^{T_{2}}|u|^{2} d t
$$

Here $u$ is the seismic signal (velocity), taken as the $I P$ or $M P$ phase; $T_{1}$ and $T_{2}$ are the initial and final times of the $I P$ and $M P$ phases $\left(t_{2}-t_{1}\right.$ or $t_{3}-t_{2}$; Fig. 9B), respectively; $r$ is the distance between the event and the recording station, assuming the epicenters of 
explosion events at the volcano summit. Within these calculations, $\rho$ is the density of the rocks forming the volcanic edifice; $c$ is the mean group velocity of Rayleigh surface waves in the region of volcano; $h$ is the thickness of the layer through which surface waves propagate; $\alpha$ is a damping factor that accounts for anelastic attenuation of the waves.

The parameters, used for calculation of the radiated seismic energy for each of three volcanoes, are listed in Table 1 . The damping factor $\alpha=A f^{\prime}$ for Rayleigh surface waves, recorded at near stations, was calculated using the empirical parameters $A$, taken as $2.4 \times 10^{-4} \mathrm{~m}^{-1}$, and $\gamma=0.4$, which were obtained by Levy et al. (2015) for Soufrière Hills Volcano. Parameter $f$ corresponds to the peak frequency of seismic signals. As seen in Fig. 6-8, the durations of the initial phases, corresponding to GSEA, may be shorter than the periods corresponding to peak frequencies of seismic signals. In these cases, the radiated seismic energy of these signals was not calculated.

The use of only vertical components of short-period seismic signals for estimation of the radiated seismic energy of explosions does not allow us to calculate the total seismic portion of the explosive energy. At the same time, the calculations performed for the explosions of three volcanoes with the same type of instruments give them comparable in the frame of article.

As was noted by Pyle (2000), the seismic portion of the total energy of an explosion represents about $10^{-5}$ of the total energy of the explosion.

\section{3. Calculation of the acoustic energy of explosion}

Acoustic energy, $E_{a}$, radiated during the Strombolian explosion process, was calculated for the Arenal volcano using the following equation (Johnson and Aster, 2005):

$$
E_{a}=2 \pi r^{2} \rho^{-1}{ }_{a t m} c^{-1}{ }_{a t m} \int^{T_{2}}|\Delta P|^{2} d t
$$


Here $T_{1}$ and $T_{2}$ are the initial and final times of the acoustic signal; $r=2.7 \mathrm{~km}$ is the distance between the crater $C$ of Arenal volcano and the recording station $S+A$ (Fig. 3), assuming the epicenters of explosion events at the volcano summit; $\rho_{a t m}=1.2 \mathrm{~kg} / \mathrm{m}^{3}$ is the air density; $c_{a t m}=0.340 \mathrm{~km} / \mathrm{s}$ is the sound speed; $\Delta P$ is an excess pressure taken from the acoustic signal.

The constant distances $r$, taken in Table 1 for each volcano and assuming the

\section{Results: Parameters of the conceptual model of two-stage Strombolian} process and their scaling relationships

The seismic energy $E_{S M S t}$, radiated during the explosion stage of the Strombolian explosions at the three volcanoes, discussed in the article, ranges within six orders, from $10^{0}$ to $10^{6} \mathrm{~J}$ (Fig. 10), demonstrating a wide spectrum in size of discussed events, beginning from low-size puff-type events recorded at Aso volcano to the large-size explosions at Arenal volcano.

\section{1. $E_{s I S t} V s . E_{s M S t}$}

The seismic energy, $E_{S I S t}$, radiated during the GSEA in the conduit at the three volcanoes, ranges for our 187 events from $1.5 \times 10^{0}$ to $6.3 \times 10^{4} \mathrm{~J}$. Fig. 11 demonstrates a strong log-log dependence of the $E_{s M S t}$ on the $E_{s I S t}$. These parameters are correlated with 
the coefficient of correlation $R=0.93\left(R_{\text {critg9\% }}=0.19\right)$ and their maximum likelihood $\log -\log$ power-law regression is

$$
\log E_{s M S t}(J)=1.09 \log E_{s I S t}(J)+1.10
$$

This result demonstrates a strong influence of the dynamics of the GSEA in the conduit on the energy of the following explosion.

\section{2. $E_{s I S t}$ and $E_{s M S t} V s . E_{a}$}

The comparison of the seismic energies, radiated during GSEA and during the explosion stage, with the acoustic energy of corresponding acoustic signals, recorded at Arenal volcano, showed that these parameters are not correlated at 99\% significance level (Fig. 12).

\subsection{The durations of the GSEAs and their distributions at the three volcanoes}

The distribution of the GSEA durations for the explosions, recorded at three volcanoes, is shown in Fig. 13. These parameters vary in a wide range for the three discussed volcanoes. For Aso events and Yasur events, the GSEA durations were characterized by narrow distributions. They varied from 0.22 to $0.75 \mathrm{~s}$ (peak of number of events at 0.35 s) and 0.44 to $1.77 \mathrm{~s}$ (peak of number of events at $0.75 \mathrm{~s}$ ), respectively. For the initial phases, recorded during the explosive events at Arenal volcano, the distribution has no exact peaks varying in a broad diapason from 1.2 to $5.4 \mathrm{~s}$.

\section{4. $E_{s M S t}$ VS. GSEA durations}

Fig. 14 shows a plot of parameters of the $E_{S M S t} V S$. the GSEA durations. It is possible to divide this plot into three zones with different type of dependence between these 
parameters. Zone 1 includes the data with GSEA durations between 0.22 and $1.3 \mathrm{~s}$, Zone 2 is represented with GSEA durations between 1.3 and $3.7 \mathrm{~s}$, and Zone 3, with GSEA durations $>3.7 \mathrm{~s}$. The most stable values of GSEA durations are observed for the eruptions at Aso volcano (Zone 1). They practically do not vary within the interval of two orders of $E_{S M S t}$. The majority of GSEA durations, estimated for the Yasur eruptions, fall within Zone 1, and only some of them indicate a low tendency of increasing the seismic energy of explosions with increasing of GSEA durations.

The source characteristics of the explosive eruptions at Arenal volcano have more complicated relationships between the parameters of $E_{S M S t}$ and GSEA durations. They are represented within all three zones of the plot on Fig. 14 indicated as Selections 1 to 3 .

Six events of Arenal volcano (Selection 1) are plotted within Zone 1. No dependence between $E_{S M S t}$ and GSEA durations is observed.

Ten eruptions of Arenal volcano (Selection 2 in Fig. 14) correspond to the GSEA parameters within Zone 2. In this case, a good dependence between the $E_{S M S t}$ and GSEA durations is observed with a coefficient of correlation $R=0.89\left(R_{\text {critg9\% }}=0.76\right)$ and representing with the maximum likelihood log-normal regression equation

$$
\log E_{s M S t}=1.33+1.42 \text { GSEA durations (s) }
$$

Two remained Arenal events, situated within Zone 3 (Selection 3), are out of the relationship indicated by Eq. 4. Considering the two events as a not representative sample of observations, we will not discuss later any regularity in their distribution.

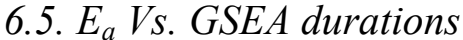

Fig. 15 demonstrates that the $E_{a}$ and the GSEA durations of 16 eruptive events at Arenal volcano with values of GSEA durations $<3.7 \mathrm{~s}$, belonging to Zones 1 and 2 of Fig. 14 , 
are inversely correlated with a coefficient of correlation $R=-0.69\left(R_{\text {crit } 99 \%}=-0.62\right)$, and their least-square log-normal regression equation is

$$
\log E_{a}(J)=8.00-0.83 \text { GSEA durations }(s)
$$

Only two events with $G S E A$ durations $\geq 3.7 \mathrm{~s}$ were out of this relationship.

The illustration of the dependence, presented in equation (5), may be seen in Fig. 6. The event of 10 April 20:43 (Fig. 6A) with the seismic energy of explosion of $2.1 \times 10^{5} \mathrm{~J}$ is characterized by GSEA durations $=1.2 \mathrm{~s}$. The acoustic signal is well seen on the seismogram (Fig. 6B) and has the maximum amplitude of $23 \mathrm{~Pa}$. At the same time, the event of 8 July 15:48 (Fig. 6D) with the close seismic energy of explosion of $1.2 \times 10^{5} \mathrm{~J}$ but characterizing by longer $G S E A$ durations $=2.4 \mathrm{~s}$, produced the acoustic signal of lower amplitude of only 4.5 $\mathrm{Pa}$ (Fig. 6E). Therefore, the event with shorter GSEA durations is characterized by larger acoustic energy while the seismic energies of two events are practically similar.

\section{Discussion}

The obtained quantitative parameters of the two stages of Strombolian eruption process, derived from the seismic and acoustic signals, and their empirical relationships, may be compared with the analytical and experimental modeling performed for analysis of the nature of Strombolian eruptions.

The scaling relationship between the seismic energy, radiated by explosions, and the seismic energy, radiated by moving gas slugs, obtained for 3 volcanoes (Eq. 3), outlines the influence of the energy of the gas slug dynamics on the magnitude of the following explosion. This type of dependence is in concordance with some published earlier analytical and laboratory results (James et al., 2009; Del Bello et al., 2012; Lane et al., 2013). 
The analytical modeling of Del Bello et al. (2012) indicated that the dynamics and vigor of slug-driven basaltic eruptions strongly depend on the gas overpressure. James et al. (2009) showed the role of the slug size in the magnitude of the subsequent explosion. Quantifying the transition between passive bubble-burst and Strombolian explosions, they qualitatively correlated overpressure in the slug with different regimes of "burst vigor". The magnitude of the measurable geophysical effects of overpressure, e.g., pressure transients and acoustic signals, was linked to the surface style of an explosion.

The laboratory experimentation, performed by Lane et al. (2013), showed that infrasonic signals measured from discrete Strombolian events in a volcanic conduit can be interpreted in terms of the gas mass flux driven by the pre- and post burst expansion of arising and expanding gas slug. Lane et al. (2013), based on the slug stability index scale from (Del Bello et al., 2012), quantified the transition between passive bubble bursting and explosive Strombolian eruptions depending on the size of gas masses. They showed that the passive expansion occurs for small gas-slug masses while for larger gas-slug masses, this transition regime transforms to fully explosive behavior.

The results of Del Bello et al. (2012) and Lane et al. (2013) are in accordance with the relationship, presented in equation (3), and indicating a common, slug-driven mechanism for all eruptive Strombolian styles, from low-energy puffing to normal Strombolian explosions.

The GSEA durations, corresponding to the seismically active gas slug passage way within the conduit or from the plug at the top of the conduit, represent an additional factor that affects the seismic and acoustic energy of discussed Strombolian explosions. Not having the confident estimations of the GSA velocity within the conduit, we will discuss these relationships in the terms of GSEA durations values. 

shows that the ascent of gas slug within the conduit represents a heterogeneous process conditioned by the specific features of the gas slug movement within the rheologicallystratified conduit during different degassing flow configurations (Capponi et al., 2016).

The seismic energy of explosions is independent on the GSEA durations for very superficial events, whose GSEA durations not exceed $1.3 \mathrm{~s}$ (Zone 1 of Fig. 14), but in the interval of the GSEA durations between 1.3 and $3.7 \mathrm{~s}$ (Zone 2 of Fig. 14), the significant positive correlation between the GSEA durations and the seismic energy $E_{s M S t}$ of subsequent explosions is observed. Therefore, at least two rheologicallydifferent zones at different depths within the conduit may be identified.

The recent studies of pyroclast textures at Strombolian-style volcanoes suggest the formation of a region of cooler, degassed, more-viscous layer (or plug) at the top of the conduit (Del Bello et al., 2015). In this case, Capponi et al. (2016) consider some possible scenarios of the gas slug flow configurations within the conduit. One of them proposes a plug sufficiently large to fully accommodate an ascending gas slug. This scenario was suggested earlier by Gurioli et al. (2014), based on the field studies at Stromboli. They proposed that the degassing magma forms a plug, or rheological layer, at the top of the conduit, through which the fresh magma bursts.

This type of plug may be considered as the upper layer of the conduit corresponding to Zone 1 in Fig. 14. The set of gas bubbles will be collected within the crack system formed at the base of the plug. Here, at very shallow depths (less than $200 \mathrm{~m}$ for Stromboli events), the gas-piston mechanism of Strombolian explosions may operate (Chouet et al., 1997). The explosions would be the result of a piston-like action of the different-size gas slugs, collected and then escaping with a high velocity from the plugtype bubble "nest" (See model of Fig. 9A) and having the same time durations of the 
ascent. In (Chouet et al., 1997), the two examples of the seismic waveforms of explosions at Stromboli, corresponding to this mechanism, have the values of GSEA durations of 1.1 and $1.3 \mathrm{~s}$, which are within the characteristic interval of the events from Zone 1. This mechanism of generation of explosions may be applied, therefore, for practically all events, occurring at volcanoes Aso and Yasur, and for a group of six explosions of Arenal.

The other scenario of Capponi et al. (2016), which may be applied for the events with GSEA durations plotted within Zone 2, proposes that in this case the gas expansion may be sufficient to drive the intrusion of low-viscosity liquid through the plug, with the slug bursting in the low-viscosity layer explosion level emplaced dynamically above the plug. This scenario may correspond to the GSEA within a conduit from the depths beneath the plug. In this case, the gas slugs will be characterized by a different depth of the initial gas expansion, generating the seismic signals, and, therefore, a greater difference in the GSEA durations.

The direct dependence of the $E_{s M S t}$ on the GSEA durations indicates homogeneity of the rheological properties of magma through which the GSEA occurs. All our events, plotted within Zone 2 of Fig. 14, were observed at the same Arenal volcano that allows considering this proposal of homogeneity as realistic enough. In these conditions, the size of seismic energy of each individual explosion will depend on the relative depth of the initial gas expansion of the slug. Deeper the process of gas expansion begins, greater following explosion will be.

The suggested existence of two scenarios of the GSEA dynamics allows to consider two types of volcanic conduits where GSEA occurs. The volcanoes of Aso and Yasur present a group of volcanoes with a plug-closed conduit. The activity of Arenal reflected a presence of at least two scenarios. For a part of explosions, the activity of the 
plug-closed type conduit is recorded (6 events within Zone 1). At the same time, 10 events, recorded within Zone 2, demonstrate the second scenario, with a plugtransparent type of conduit. As one of possible explanations, may be taken in this case the proposal of Lesage et al. (2006) about existence of two seismic sources, associated with two magmatic conduits at Arenal. Then, the case of Arenal explosions may be result of the double-nature of the volcanic conduit having two active ways for GSA, the plug-closed and the plug-transparent.

The significant inverse dependence of acoustic energy, $E_{a}$, of Arenal explosions on the GSEA durations, shown in Fig. 15, indicates two important points in generation of acoustic energy of the explosions. At first, the acoustic energy of explosions was emitted not only during the slug burst on the surface but also during the GSEA within the conduit. Second, the size of finally emitted on the surface acoustic energy depends on the values of GSEA durations: with longer GSEA durations, the greater loose of acoustic energy occurs before gas slug reaches the surface.

These observations are in accordance with the results obtained at Stromboli volcano. The beginning of emission of acoustic energy at depth within the conduit was revealed from analysis of acoustic pressure, recorded by Vergniolle and Brandeis (1994) during several explosions on Stromboli volcano. They concluded that the vibration and bursts of the bubbles during slug ascent yields most part of acoustic energy. Ripepe et al. (2001) also supposed that the sources of acoustic signals, recorded during the explosions at Stromboli, may not coincide with the magma free surface but occur within the conduit.

The next subject for discussion represents the relation between the acoustic and seismic energies radiated during the Strombolian process. As was shown in Fig. 12A, the acoustic energy is not correlated with the $E_{S M S t}$ at Arenal volcano. This may be 
conditioned by the significant loose of acoustic energy within the conduit during the GSEA. The acoustic energy is not correlated with $E_{s I S t}$ also (Fig. 12B).

The volcano acoustic-seismic ratio was studied for Strombolian eruptions of Karymsky (Kamchatka) and Erebus (Antarctica) by Johnson and Aster (2005). Their results also demonstrated the absence of correlation between these parameters.

Generally, the analysis of relationships between the two stage characteristics, derived from the seismic and acoustic signals, indicated the influence of the parameters of the moving gas slug, such as the radiated seismic energy and durations of gas-slug ascent within the conduit, on the manifestations of Strombolian eruptions, including the seismic and acoustic energy of explosions.

The proposed two-stage conceptual model of Strombolian eruption does not exclude the existence of other models based on more complicated seismic and acoustic signals of Strombolian explosions.

\section{Conclusions}

The study of seismic records, associated with Strombolian eruptions at volcanoes Arenal, Aso and Yasur, showed a two-phase structure of majority of these seismic signals that may be the result of the two-stage eruptive process. In the frame of proposed two-stage conceptual model of Strombolian eruption, the initial stage is defined as the process of gas-slug expansion and ascent within the volcanic conduit or gas-slug ascent from the plug at the top of the conduit. The second stage is supposed as an explosion occurring at the surface due to the gas slug burst. Analysis of relationships between the parameters of two stages, derived from the seismic and acoustic signals, indicated the influence of the gas slug dynamics on the surface manifestations of Strombolian explosions. 
Acknowledgements. We thank the Editor Vernon Cormier for his kind attention. The comments of anonymous reviewer helped us to improve the text. William G. Melson provided V.Z. with the observations of the temporal seismo-acoustic station, installed near Arenal volcano in 1991, during his stay at Colima Volcano Observatory in 1997. The processing of the digital seismic and acoustic signals was realized using the program DEGTRA provided by Mario Ordaz, UNAM and the Interactive MATLAB software for the analysis of seismic volcanic signals prepared by Philippe Lesage (Lesage, 2009) and adapted by Miguel Gonzalez.

\section{References}

Alvarado Induni, G.E. (2000). Volcanes de Costa Rica: geología, historia y riqueza natural. EUNED, San José, 284 p.

Alvarado, G. E., W. Taylor, M. Ohmberger, G. Soto, and L. Madrigal (1997). First observations of volcanic seismicity at Arenal volcano (Costa Rica) using a new three-component seismic digital network, Boletín del Observatorio Sismológico y Vulcanológico de Arenal y Miravalles, 15, 11-45.

Alvarado, GE and Soto, GJ (2002). Pyroclastic flow generated by crater wall collapse and outpouring of the lava pool of Arenal Volcano, Costa Rica. Bull Volcanol $63: 557-568$

Battaglia, J., J. P. Métaxian, and E. Garaebiti (2016a). Families of similar events and modes of oscillation of the conduit at Yasur volcano (Vanuatu). J. Volcanol. Geotherm. Res., 322, 96-111. doi:10.1016/j.jvolgeores.2015.11.003.

Battaglia, J., Métaxian, J.-P., Garaebiti, E. (2016b). Short term precursors of Strombolian explosions at Yasur volcano (Vanuatu). Geophys. Res. Lett., 43, 
doi:10.1002/2016GL067823.

BGVN (2015). Report on Asosan (Japan). Bulletin of the Global Volcanism Network, 40, 2. http://dx.doi.org/10.5479/si.GVP.BGVN201502-282110

Brothelande, E., Lenat, J.-F., Chaput, M., Cailler, L., Finizola, A., Dumont, S., Peltier, A., Bachelery, P., Barde-Cabusson, S., Byrdina, S., Menny, P., Colonge, J., Douillet, G.A., Letort, J., Letoumeur, Merle, 0., Di Gangi, F., Nakedau, D., and Garaebiti, E. (2016). Structure and evolution of an active resurgent dome evidenced by geophysical investigations: The Yenkahe dome-Yasur volcano system (Siwi caldera, Vanuatu). J. Volcanol. Geotherm. Res., 322, 241-262. doi: 10.1016/j.jvolgeores.2015.08.021.

Borgia, A., Poore, C., Carr, M.J., Melson, W.G., Alvarado, G.E. (1988). Structural, stratigraphic, and petrologic aspects of the Arenal-Chato volcanic system, Costa Rica; evolution of a young stratovolcanic complex. Bull. Volcanol. 50 (2), 86105.

Bottiglieri, M., De Martino, S., Falanga, M., Godano, C., Palo, M. (2005). Statistics of inter-time of Strombolian explosion-quakes. Europhys. Lett. 72, 492-498.

Capponi, A., James, M.R., Lane, S.J. (2016). Gas slug ascent in a stratified magma: implications of flow organisation and instability for Strombolian eruption dynamics. Earth Planet. Sci. Lett. $435 \quad$ (1): 159-170. https://doi.org/10.1016/j.eps1.2015.12.028.

Chouet, B., Saccorotti, G., Martini, M., Dowson, P., De Luca, G., Milana G., and Scarpa, R. (1997). Source and path effects in the wave fields of tremor and explosions at Stromboli volcano, Italy. J. Geophys. Res. 102, 15129-15150. 

and generation mechanisms of pyroclastic flows at Arenal volcano, Costa Rica between 1987 and 2001. Bull Volcanol, 67:695-716.

De Lauro, E., De Martino, S., Falange, M., Palo, M. (2009). Modelling the macroscopic behavior of Strombolian explosions at Erebus volcano. Phys. Earth Planet. Inter., 176, 174-186

Del Bello, E., E. W. Llewellin, J. Taddeucci, P. Scarlato, and S. J. Lane (2012), An analytical model for gas overpressure in slug-driven explosions: Insights into Strombolian volcanic eruptions, J. Geophys. Res., 117, B02206, doi:10.1029/2011JB008747.

Del Bello, E., Lane, S.J., James, M.R., Llewellin, E.W., Taddeucci, J., Scarlato, P., Capón, A. (2015). Viscous plugging can enhance and modulate explosivity of strombolian eruptions. Earth and Planetary Science Letters 423: 210-218.

Gurioli, L., L. Colo', A. J. Bollasina, A. J. L. Harris, A. Whittington, and M. Ripepe (2014), Dynamics of Strombolian explosions: Inferences from field and laboratory studies of erupted bombs from Stromboli volcano, J. Geophys. Res. Solid Earth, 119, 319-345, doi:10.1002/2013JB010355.

Harris, A., and M. Ripepe (2007). Synergy of multiple geophysical approaches to unravel explosive eruption conduit and source dynamics - A case study from Stromboli. Chemie der Erde, 67, 1-35. doi:10.1016/j.chemer.2007.01.003

Hibert, C., Malet, J-F., Bourrier, F., Provost, F., Berger, F., Bornemann, P., Tardif, P. and Mermin, E. (2017). Single-block rockfall dynamics inferred from seismic signal análisis. Earth Surf. Dynam., 5, 283-292.

James, M. R., S. J. Lane, L. Wilson, and S. B. Corder (2009). Degassing at low magma-viscosity volcanoes: Quantifying the transition between passive bubble-burst 
and Strombolian eruption, J. Volcanol. Geotherm. Res., 180, 81-88, doi:10.1016/j.jvolgeores.2008.09.002.

Jaupart, C., and S. Vergniolle (1988). Laboratory models of Hawaiian and Strombolian eruptions, Nature, 331, 58-60, doi:10.1038/331058a0.

Johnson, J.B. (2003). Generation and propagation of infrasonic airwaves from volcanic explosions. J. Volcanol. Geotherm. Res. 121, 1-14.

Johnson, J. B., Aster, R. C. (2005). Relative partitioning of acoustic and seismic energy during Strombolian eruptions J. Volcanol. Geotherm. Res. 148, 334-354.

Komazawa, M. (1995). Gravimetric analysis of Aso volcano and its interpretation. J Geod Soc Jpn, 41,17-45.

Kremers, S., Y. Lavallée, J. Hanson, K.-U., Hess, M. O. Chevrel, J. Wassermann, and D. B. Dingwell (2012). Shallow magma-mingling-driven Strombolian eruptions at Mt. Yasur volcano, Vanuatu, Geophys. Res. Lett., 39, L21304, doi:10.1029/2012GL053312.

Lane, S.J., James, M.R., Corder, S.B. (2013). Volcano infrasonic signals and magma de-gassing: first-order experimental insights and application to Stromboli. Earth Planet. Sci. Lett.377-378, 169-179.

Lautze, N.C. and Houghton, B.F. (2007). Linking variable explosion style and magma textures during 2002 at Stromboli volcano, Italy. Bull. Volcanol., 69, 445-460.

Lesage, P. (2009). Interactive Matlab software for the analysis of seismic volcanic signal. Computers \& Geosciences 35, 2137-2144.

Lesage, P., M. M. Mora, G. E. Alvarado, J. Pacheco, and J.-P. Métaxian (2006). Complex behavior and source model of the tremor at Arenal volcano, Costa Rica, J. Volcanol. Geotherm. Res., 157(1-3), 49-59, doi:10.1016/j.jvolgeores.2006.03.047. 
Levy, C., A. Mangeney, F. Bonilla, C. Hibert, E. S. Calder, and P. J. Smith 630 (2015). Friction weakening in granular flows deduced from seismic records at the

Soufrière Hills Volcano, Montserrat, J. Geophys. Res. Solid Earth, 120.

Marchetti, E., M. Ripepe, D. Delle Donne, R. Genco, A. Finizola, and E. Garaebiti (2013). Blast waves from violent explosive activity at Yasur Volcano, Vanuatu, Geophys. Res. Lett., 40, 1-6. doi:10.1002/2013GL057900.

Mora, M.M., Lesage, P., Valette. B., Alvarado, G.E., Leandro, C., Metaxian, JP., Dorel. J. (2006). Shallow velocity structure and seismic site effects at Arenal volcano, Costa Rica. J. Volcanol. Geotherm. Res. 152, 27- 65.

Nakamichi, H., Iguchi, M., Tameguri, T., and Sonoda, T. (2017). Quantification of seismic and acoustic waves to characterize the 2014 and 2015 eruptions of Kuchinoerabujima Volcano, Japan. J. Natur. Disas. Sci., 38, 65-83.

Newhall, C.G., and Self, S. (1982). The volcanic explosivity index (VEI): an estimate of explosive magnitude for historical volcanism. J. Geophys. Res. (Oceans and Atmospheres), 87, 1231-1238.

Parfitt, E. A., and L. Wilson (1995). Explosive volcanic eruptions-IX. The transition between Hawaiian-style lava fountaining and Strombolian explosive activity. Geophys. J. Int., 121(1), 226-232, doi:10.1111/j.1365-246X.1995.tb03523.x. Pering, T.D., McGonigle, A.J.S., James, M.R., Capponi, A., Lane, S.J., Tamburello, G., Aiuppa, A. (2017). The dynamics of slug trains in volcanic conduits: Evidence for expansion driven slug coalescence. J. Volcanol. Geotherm. Res. 348, 2635.

Perrier, L., Métaxian, J-P., Battaglia, J. and Garaebiti, E. (2012). Estimation of the near-surface velocity structure of the Yasur-Yenkahe volcanic complex, Vanuatu. J. Volcanol. Geotherm. Res., 227-228, 50-60. 
Pyle, D. M. (2000). Sizes of volcanic eruptions, in Encyclopedia of Volcanoes,

edited by H. Sigurdsson, pp. 263-269, Elsevier, New York.

Ripepe, M., Ciliberto, S. and Della Schiava, M. (2001). Time constraints for modelling source dynamics of volcanic explosions at Stromboli. J. Geophys. Res., 106, 8713-8727.

Spina, L., Taddeucci, J., Cannata, A., Gresta, S., Lodato, L., Privitera, E., Scarlato, P., Gaeta, M., Gaudin, D., Palladito, D.M. (2015). Explosive volcanic activity at Mt. Yasur: A characterization of the acoustic events (9-12th July 2011). J. Volcanol. Geotherm. Res., 302, 24-32.

Taddeucci, J., Edmonds, M., Houghton, B., James, M.R., and Vergniolle, S. (2015). Hawaiian and Strombolian Eruptions. In "Encyclopedia of Volcanoes" (H. Sigurdsson, Ed.), 2d edition, pp. 485-503. Academic Press, Amsterdam - Tokyo. Tameguri, T., Iguchi, M., and Ishihara, K. (2002). Mechanism of explosive eruptions from moment tensor analyses of explosion earthquakes at Sakurajima volcano, Japan. Bull. Volcanol. Soc. Japan 47, 197-215.

Tsutsui, T., Sudo, Y., Mori, T., Katsumata, K., Tanaka, S., Oikawa, J., Tomatsu, T., Matsuo, N., Matsushima, K., Miyamachi, H., Nishi, K., Fujiwara, Y., and Hiramatsu, H. (2003). 3-D seismic velocity structure beneath the edifice of central cones of Aso Volcano. Bull. Volcanol. Soc. Japan (Kazan), 48, 293, 3-7.

Vergniolle, S., and G. Brandeis (1994). Origin of the sound generated by Strombolian explosions, Geophys. Res. Lett., 21(18), 1959-1962, doi:10.1029/94GL01286.

Vergniolle, S. and Brandeis,G. (1996). Strombolian explosions 1. A large bubble breaking at the surface of a lava column as a source of sound. J.Geophys.Res.101(B9), 20433-20447. 
680 "Encyclopedia of Volcanoes" (H. Sigurdsson, Ed.), pp. 447-461. Academic Press, San 681 Diego.

Zobin, V.M., Navarro, C., Reyes-Dávila, G., Orozco, J., Bretón, M., Tellez, A., 683 Reyes-Alfaro, G. and Vázquez, H. (2006). The methodology of quantification of volcanic explosions from broadband seismic signals and its application to the 2004685 2005 explosions at Volcán de Colima, México. Geophys. J. Int., 167, No 1, 467-478.

686

687

690

691

692

693

694 
Figures

Fig. 1. Index-map of volcanoes with Strombolian explosions discussed in the article. Map is taken from https://www.mapsland.com/world/large-political-map-of-the-world1995.

Fig. 2. Waveforms of seismic and acoustic signals recorded during Strombolian eruptions. In A, we show the characteristic seismic and acoustic waveforms recorded during explosion at Stromboli volcano. The signal was taken from Chouet et al. (1997). In B, we show a typical seismic two-phase waveform of Strombolian explosion recorded at Aso volcano and similar to the signal recorded at Stromboli, shown in A. The signals of this type were selected for our study. In C, a waveform of Strombolian explosion at Yasur volcano represents an example of the signal which has not a two-phase structure. This type of signals was not selected for our study. IP is the initial phase; MP is the main phase.

Fig. 3. A view of a typical Strombolian explosion at Arenal volcano taken by W. Melson on 4 April 1990 from the joint OVSICORI-UNA/Smithsonian Institution Volcano Observatory, situated about $2.5 \mathrm{~km}$ south of the volcano (A) and a system of monitoring of the volcano (B). The indices $A, B, C$ in Fig. B correspond to the craters, opened during the 1968 eruption on the western flank of the volcano; index $D$ corresponds to the old summit crater formed before the 1968 eruption. Active crater C, origin of Strombolian explosions, discussed in the article, is marked with a rectangle. Triangle with index $\mathrm{S}+\mathrm{A}$ shows the position of the seismic and acoustic sensors.

Fig. 4. A view of a typical Strombolian explosion at Aso volcano taken by Y. Sudo on 7 December 2014 (A) and a system of monitoring of the volcano (B). Triangle with index KAF shows the position of the seismic sensors.

Fig. 5. A view of a typical Strombolian explosion at Yasur volcano taken by Yashmin Chebly (https://www.volcanodiscovery.com/photos/yasur/0808/p2.html) in August 2008 (A) and a system of monitoring of the volcano (B). In B, indices A, B and C 
correspond to three active craters. Triangle with index Y05 shows the position of the seismic sensor. Map in B was modified from Marchetti et al. (2013).

Fig. 6. The short-period (vertical component) seismic (A, D) and corresponding acoustic (B, E) signals of Strombolian explosions recorded at a distance of $2.7 \mathrm{~km}$ from the crater $\mathrm{C}$ of Arenal volcano. The Fourier spectra of the initial (IP) and main (MP) phases, marked at seismograms within arrows with labels $t 1$ and $t 2$, and $t_{2}$ and $t 3$, respectively, are shown in Figs. C and F. The acoustic signals, corresponding to the seismic records of Strombolian explosions in B and E, are shown within rectangles.

Fig. 7. The short-period (vertical component) seismic signals recorded at a distance of $150 \mathrm{~m}$ from the crater of Aso volcano (A, C, E). Corresponding Fourier spectra of the initial $(I P)$ and main $(M P)$ phases, marked at seismograms within arrows with labels $t 1$ and $t_{2}$, and $t_{2}$ and $t 3$, respectively, are shown in Figs. B, D and F.

Fig. 8. The short-period (vertical component) seismic signals recorded at a distance of $650 \mathrm{~m}$ from the crater of Yasur volcano (A, C, E). Corresponding Fourier spectra of the initial (IP) and main (MP) phases, marked at seismograms within arrows with labels $t 1$ and $t_{2}$, and $t_{2}$ and $t 3$, respectively, are shown in Figs. B, D and F.

Fig. 9. Illustration of the two-stage model of Strombolian explosion (A) and corresponding broad-band seismic record (B). The elements of the model, radiating the seismic and acoustic signals, are indicated. Photo of Strombolian explosion at Krakatau volcano (4 June 2009) was taken by T. Pfeiffer (https://www.volcanodiscovery.com/photos/strombolian_eruptions/image94.html).

Fig. 10. Distribution of the seismic energy radiated by explosions for 193 Strombolian events of volcanoes Arenal, Aso and Yasur.

Fig. 11. Dependence of the seismic energy radiated by explosions on the seismic energy radiated during ascent of gas slugs for 193 Strombolian events of volcanoes Arenal (red diamonts), Aso (blue circles) and Yasur (brown triangles). 
Fig. 12. Dependence of the acoustic energy of Strombolian explosions of Arenal

volcano on the seismic energy radiated by explosions (A) and moving gas slugs (B).

Fig. 13. Distribution of the durations of seismically active ascent of gas slugs for 193 Strombolian events of volcanoes Arenal, Aso and Yasur.

Fig. 14. Dependence of the seismic energy radiated by Strombolian explosions of volcanoes Arenal, Aso and Yasur on the durations of seismically active ascent of gas slugs. Three zones corresponding to different durations of the gas-slug ascent are separated with two vertical lines. Regression line is shown for 10 events of Arenal volcano generated within Zone 2. Indices for the events of different volcanoes are the same as in Fig. 11.

Fig. 15. Dependence of the acoustic energy of explosions on the durations of seismically active ascent of gas slugs for 18 Strombolian events of Arenal volcano. Regression line is shown for 16 events. Two events, surrounding by an ellipse, are out of this regression. 


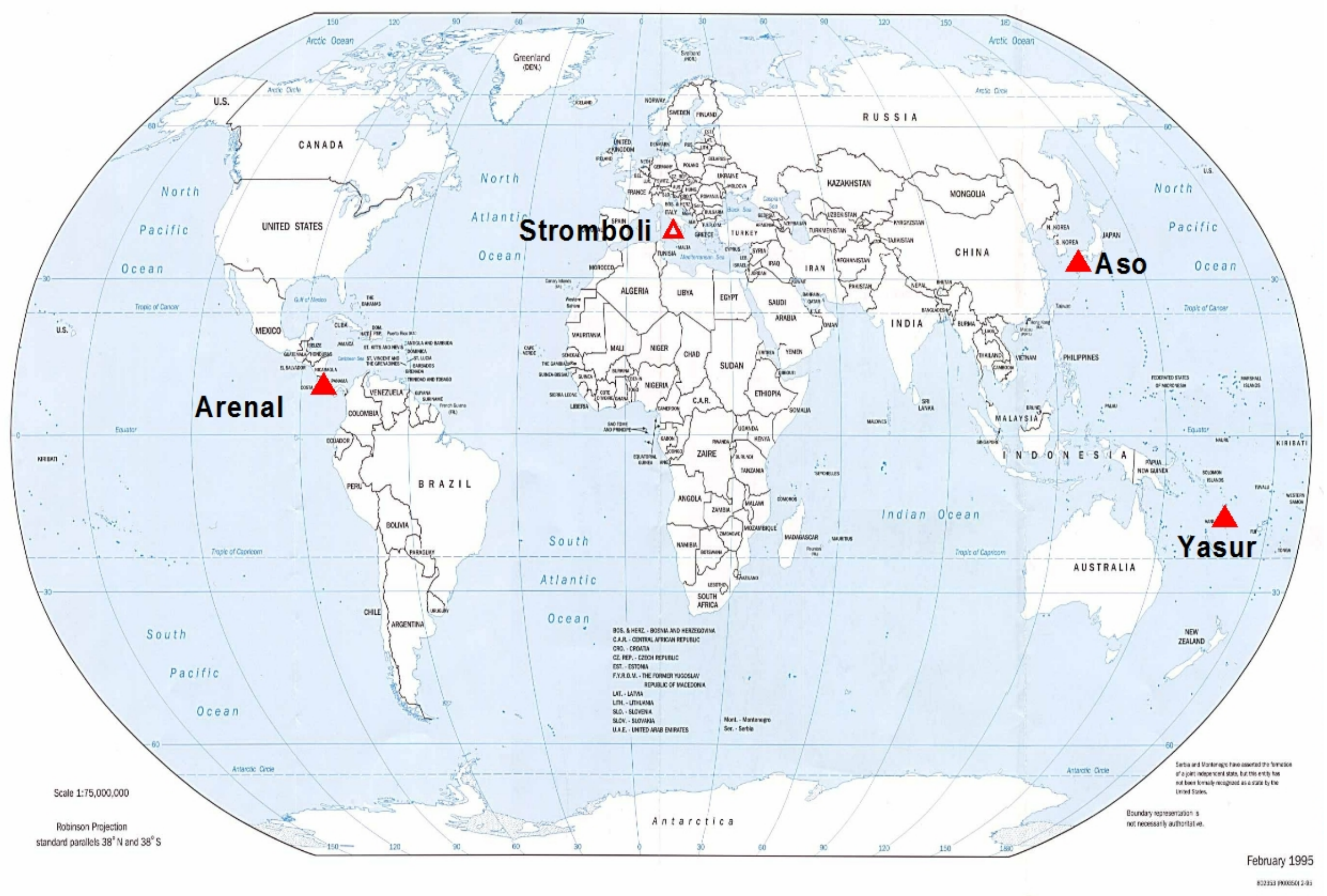



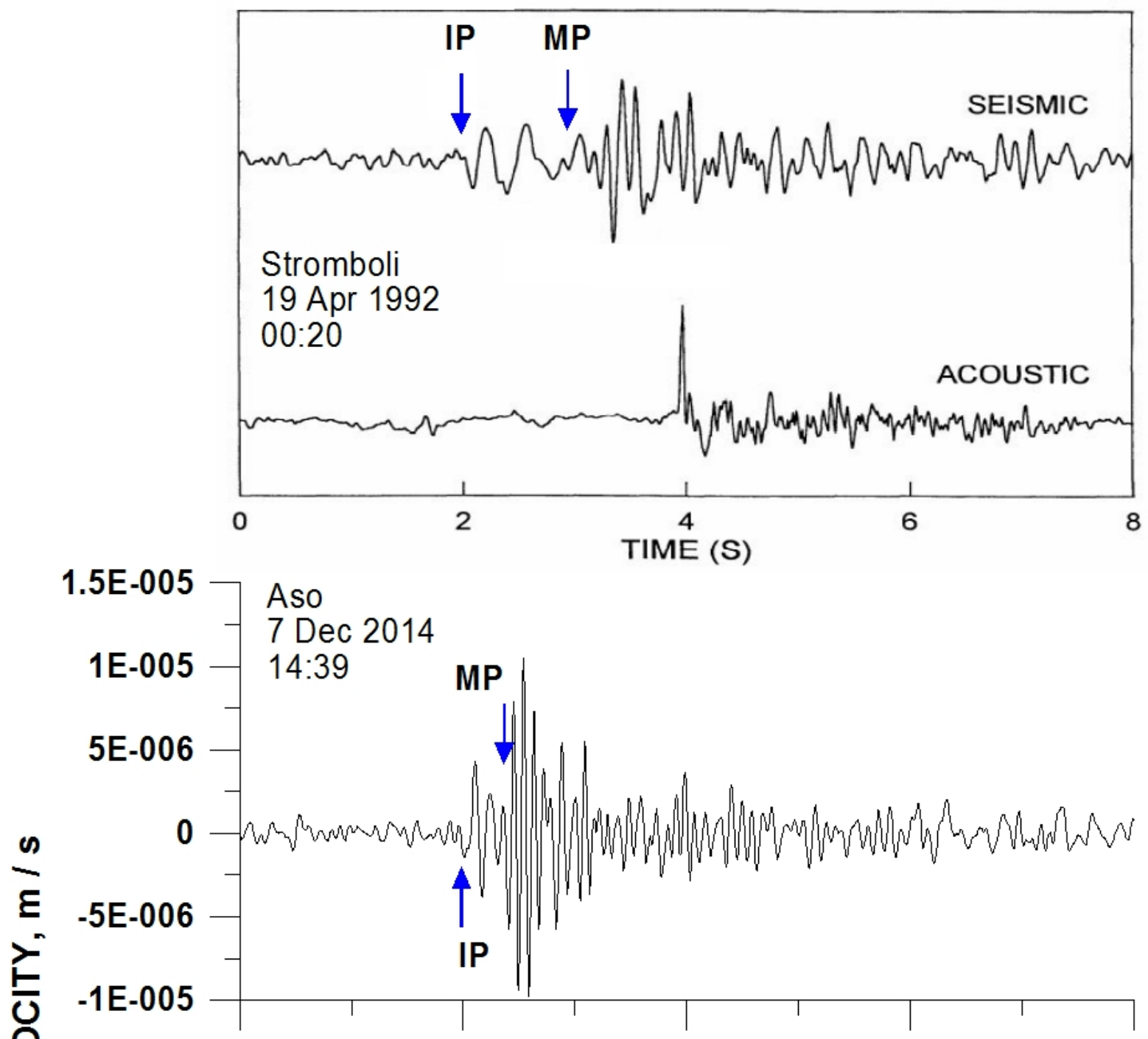

B

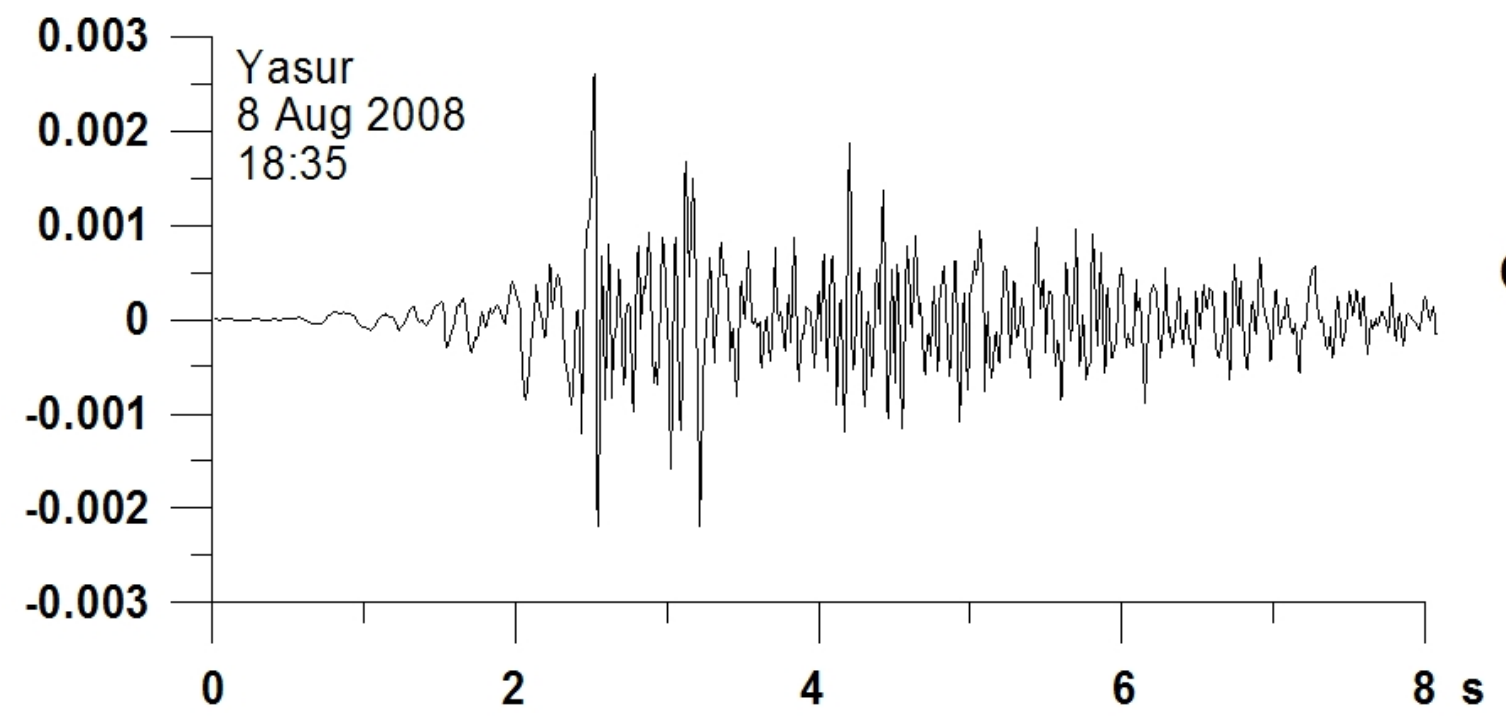



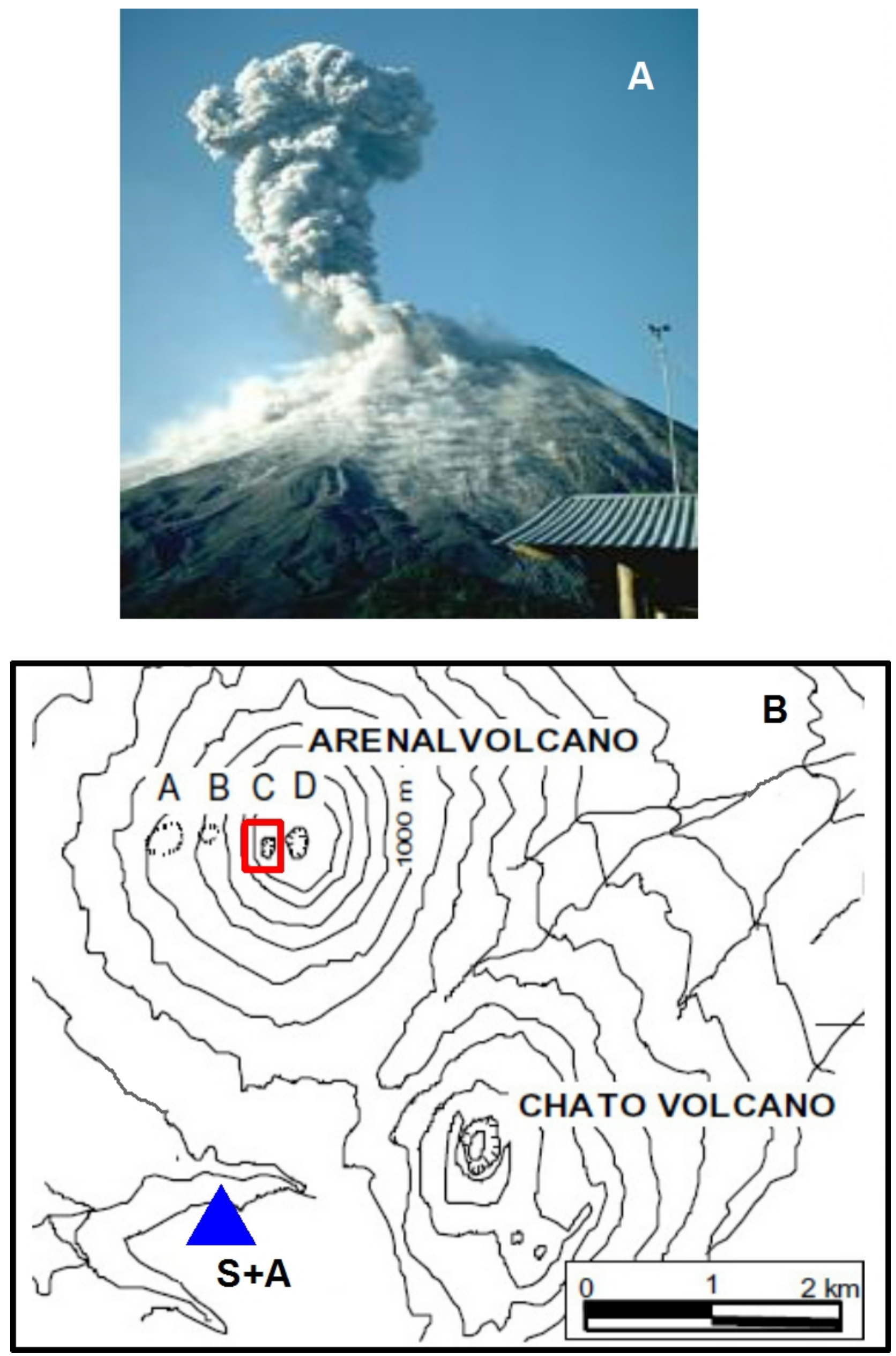

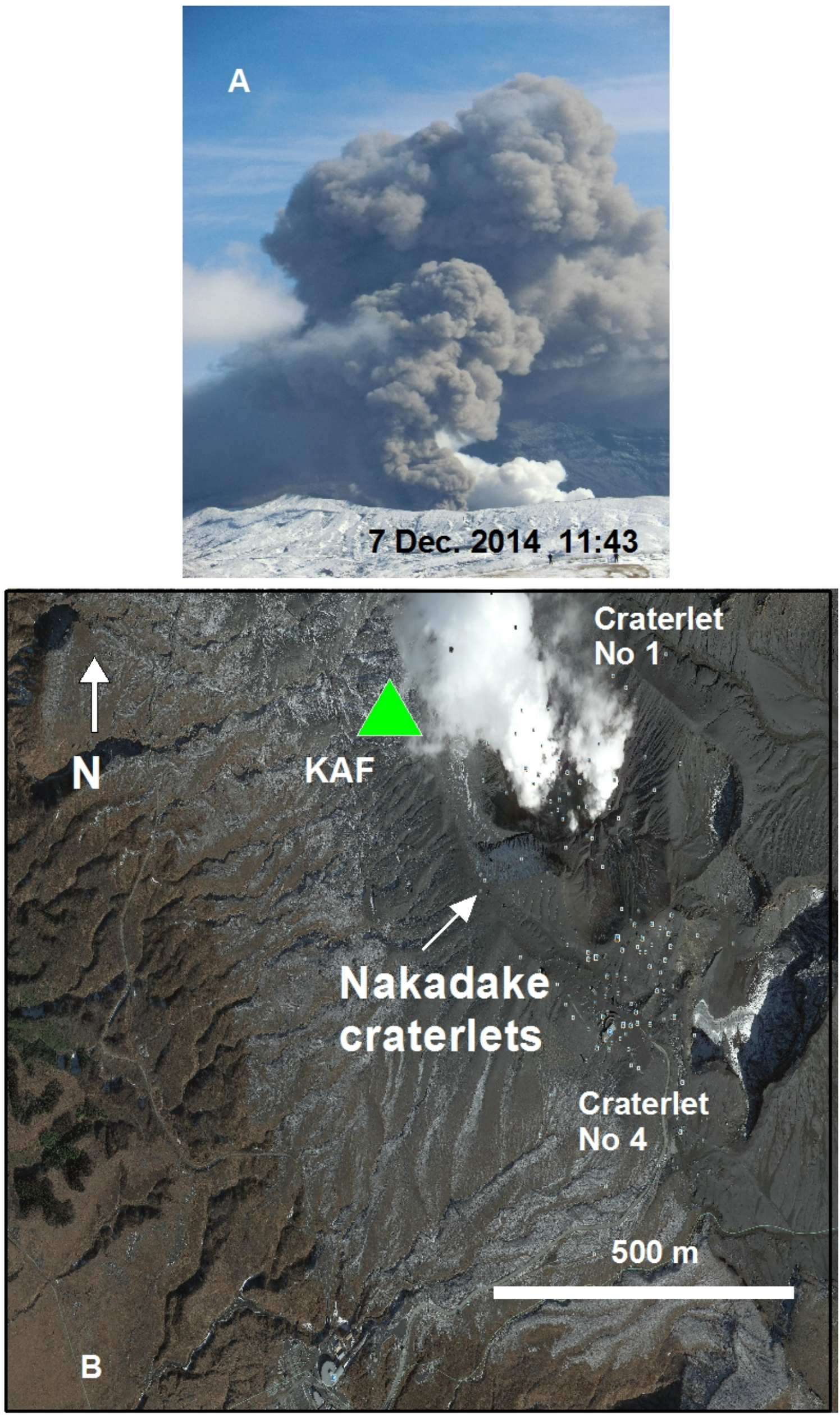
A

August

2008

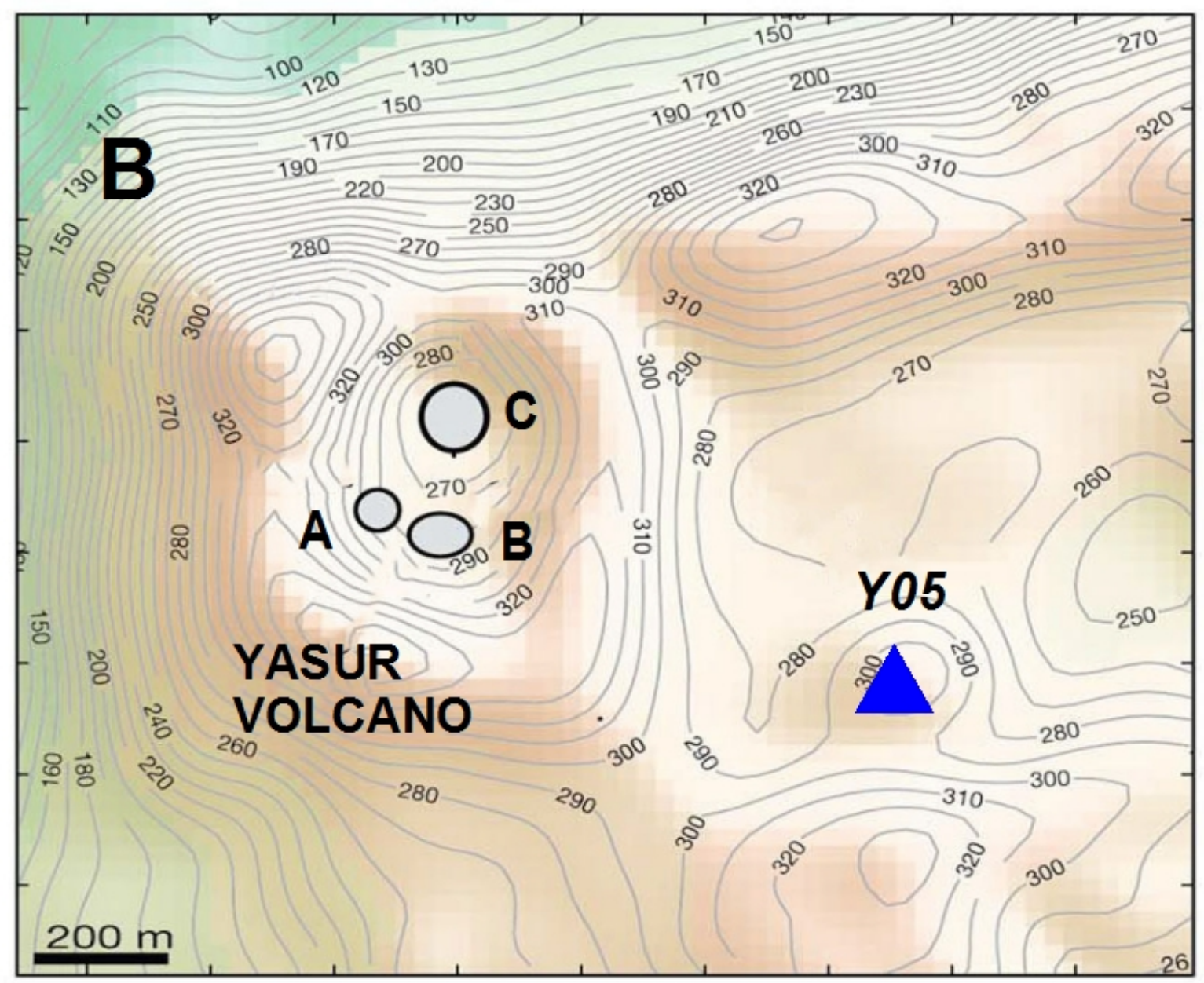




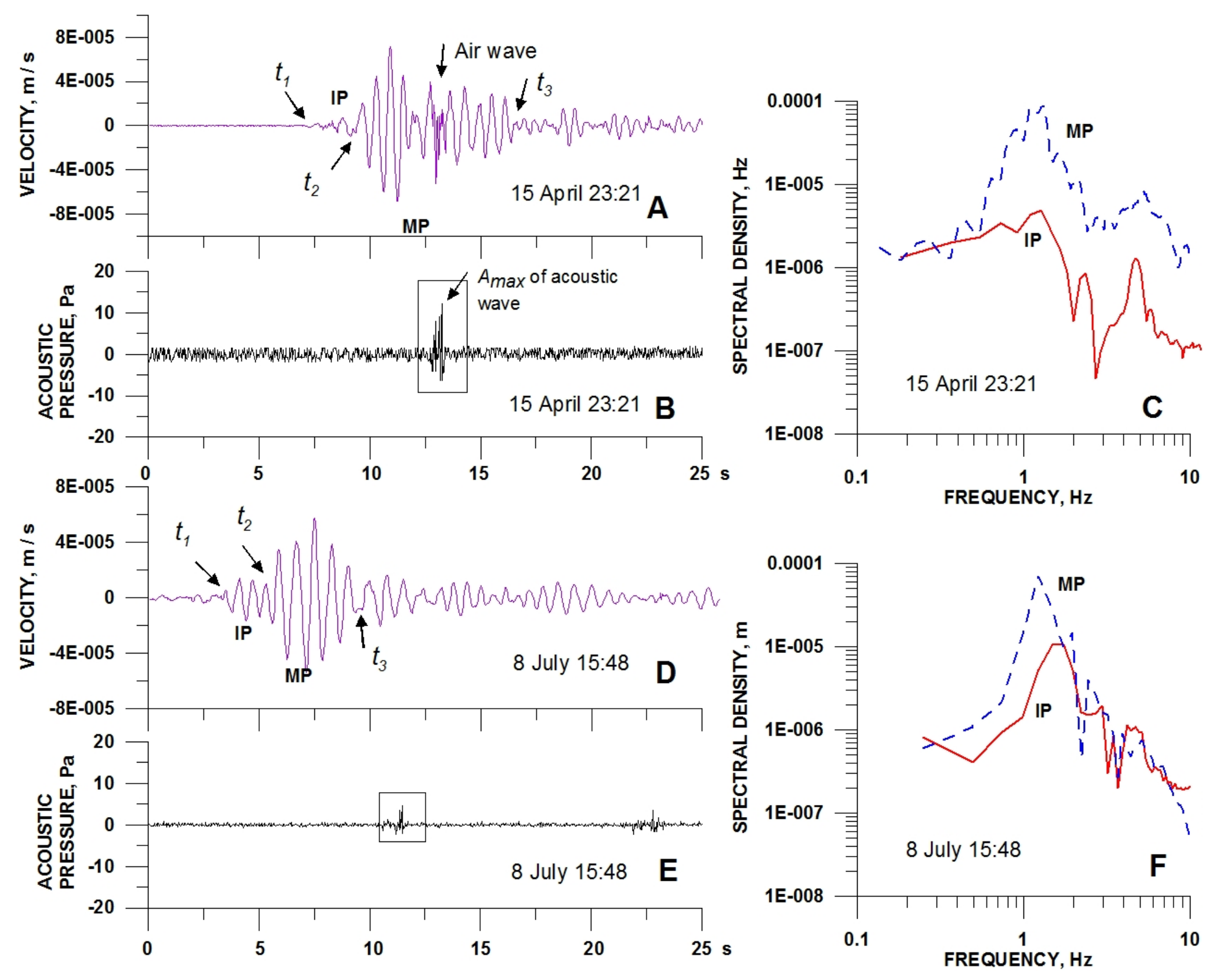



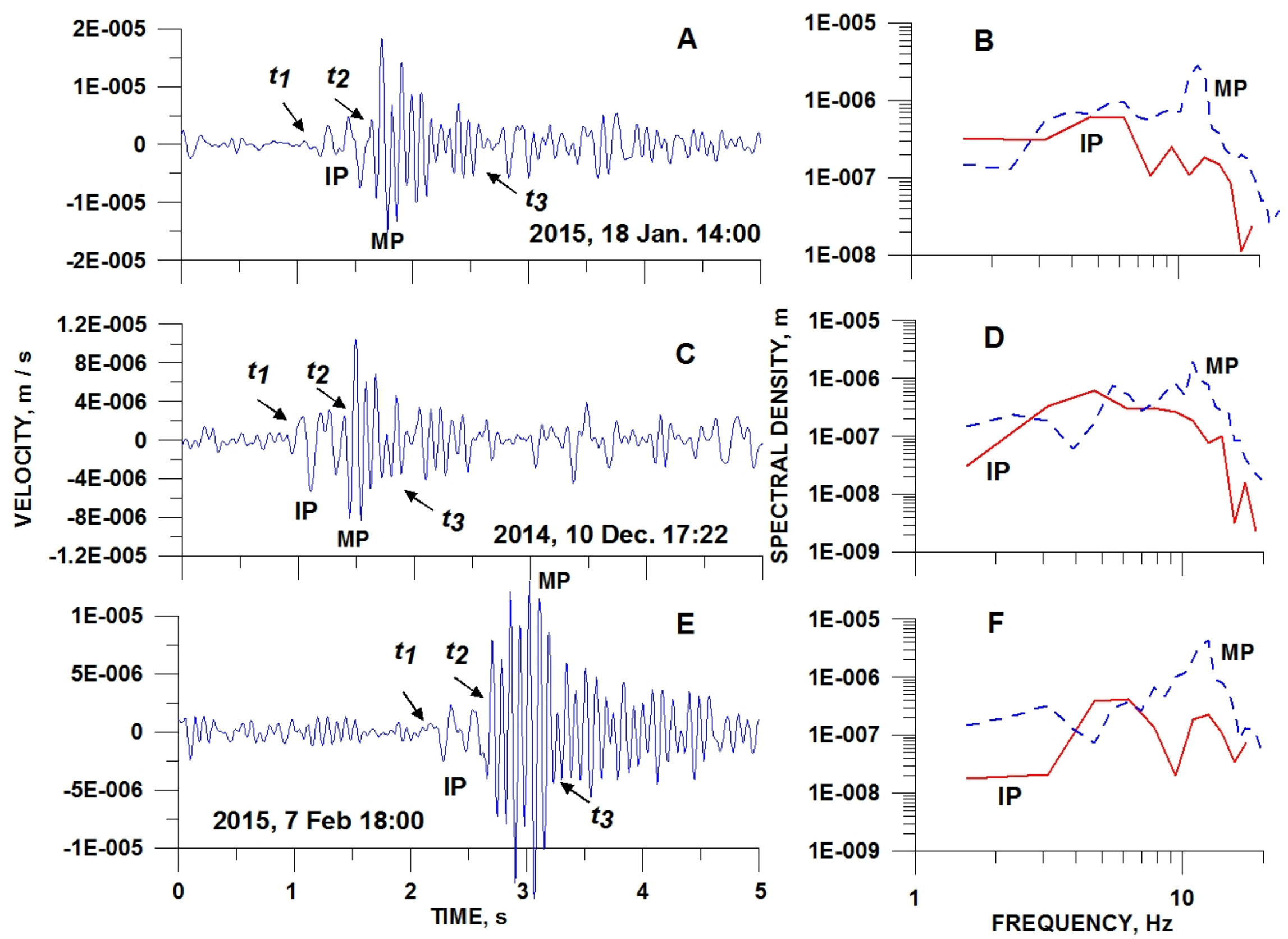

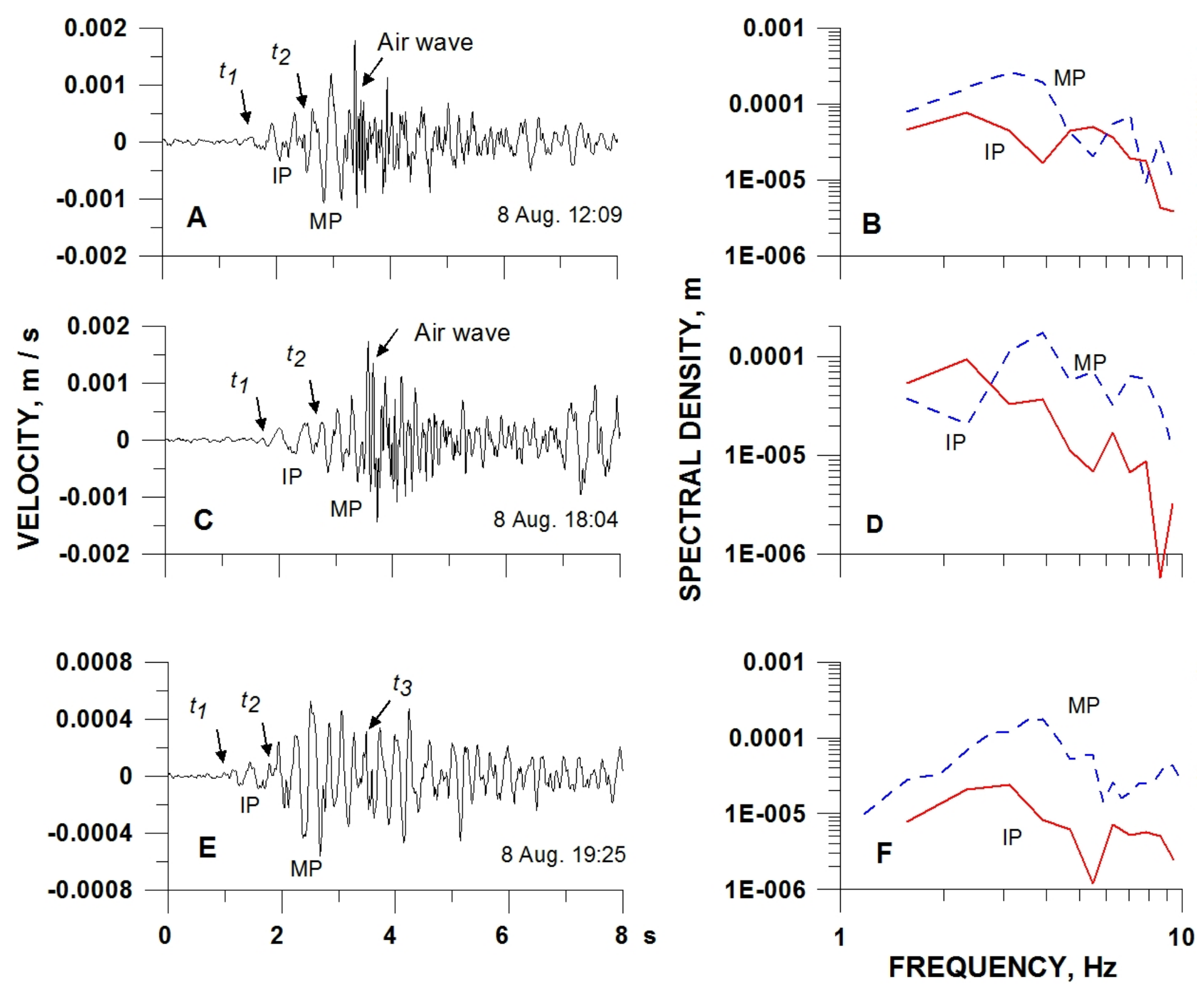

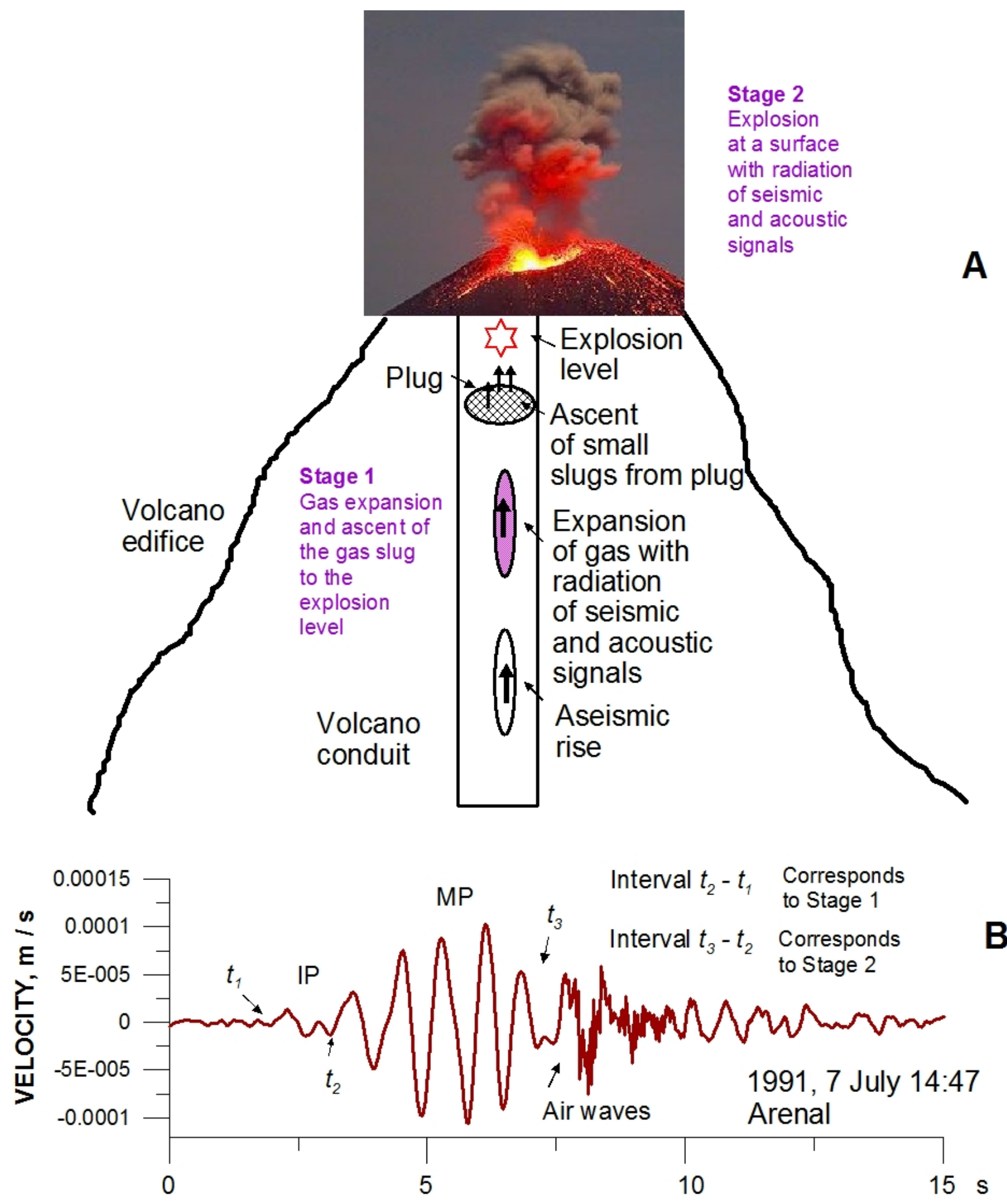


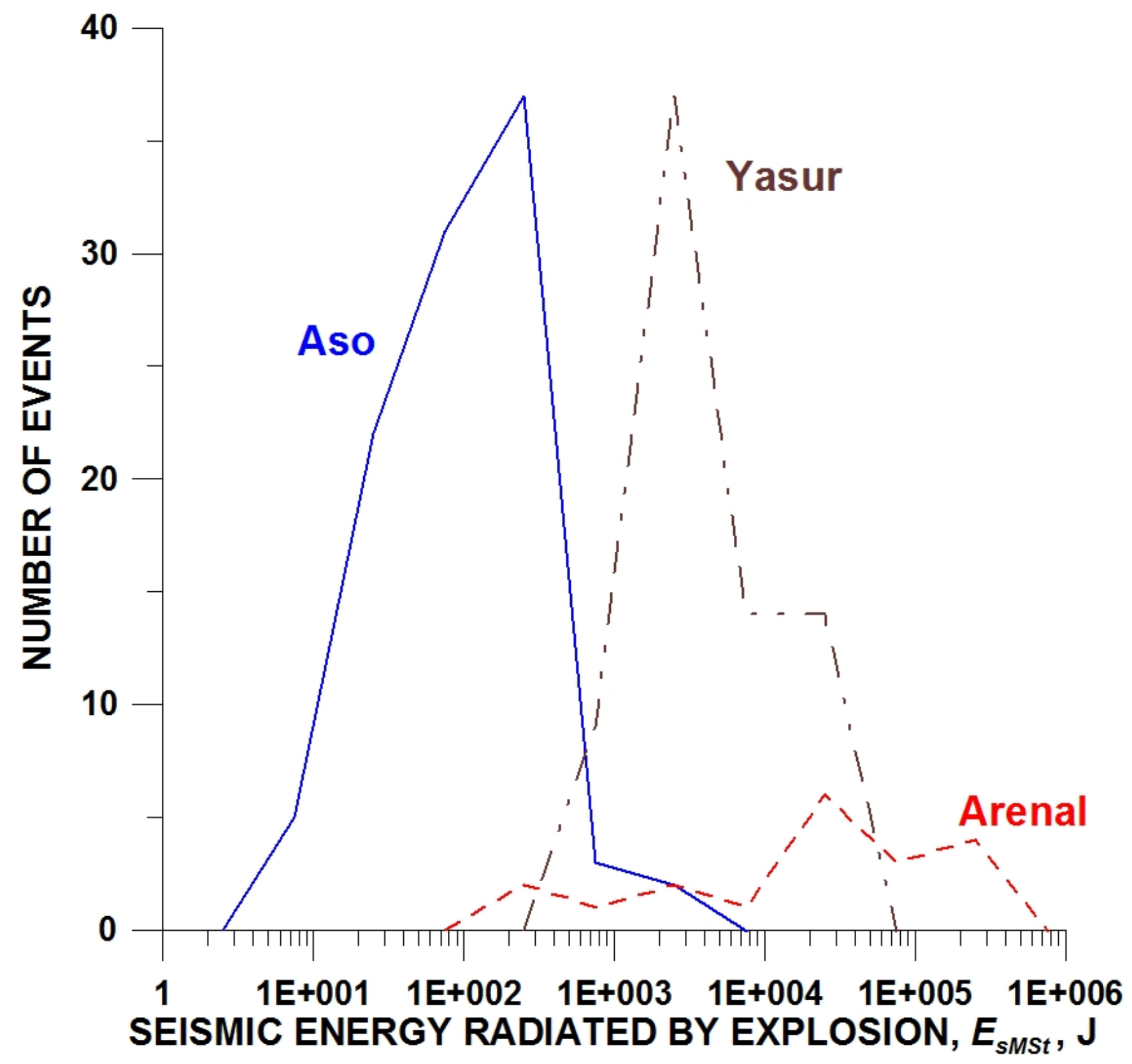




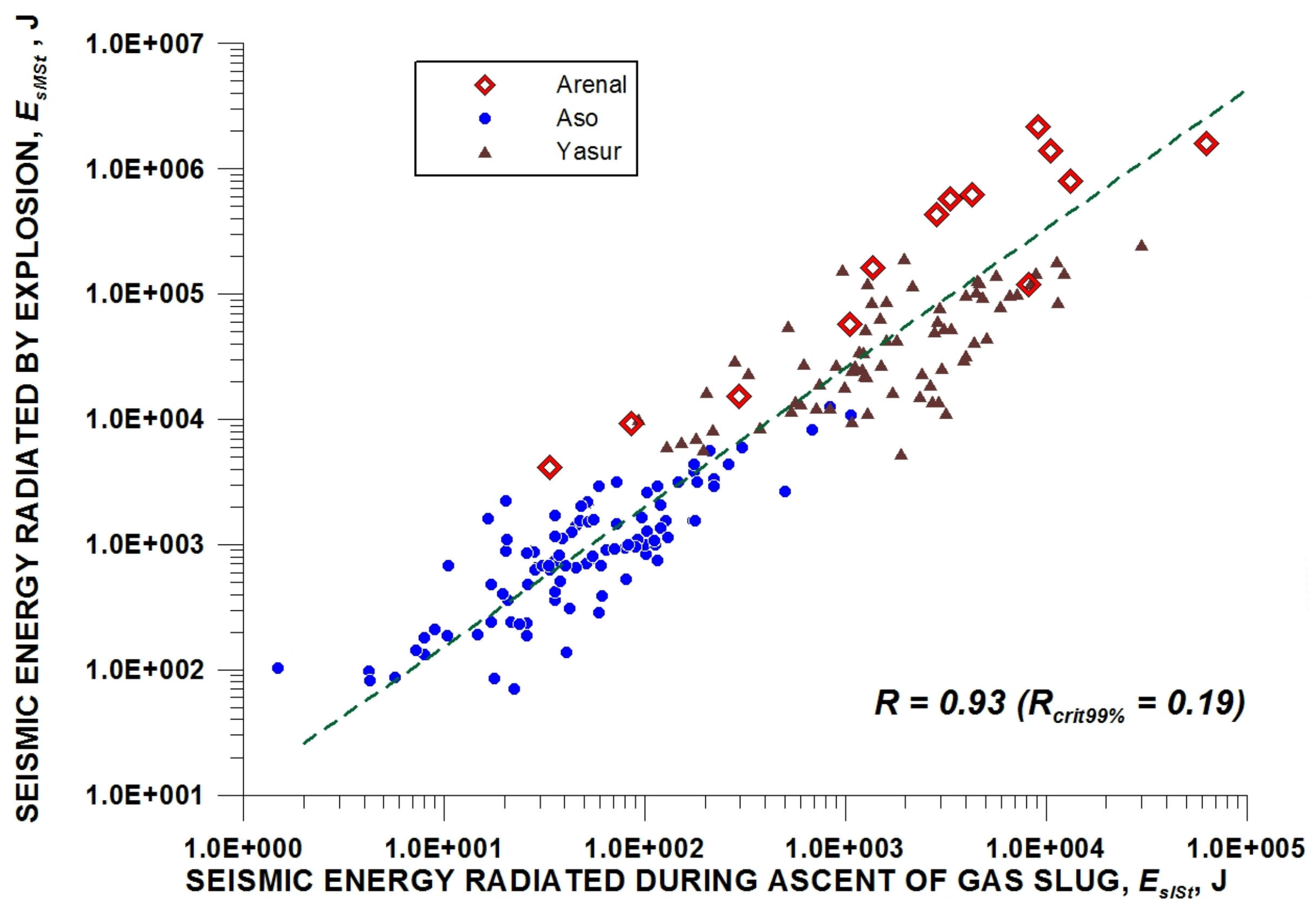



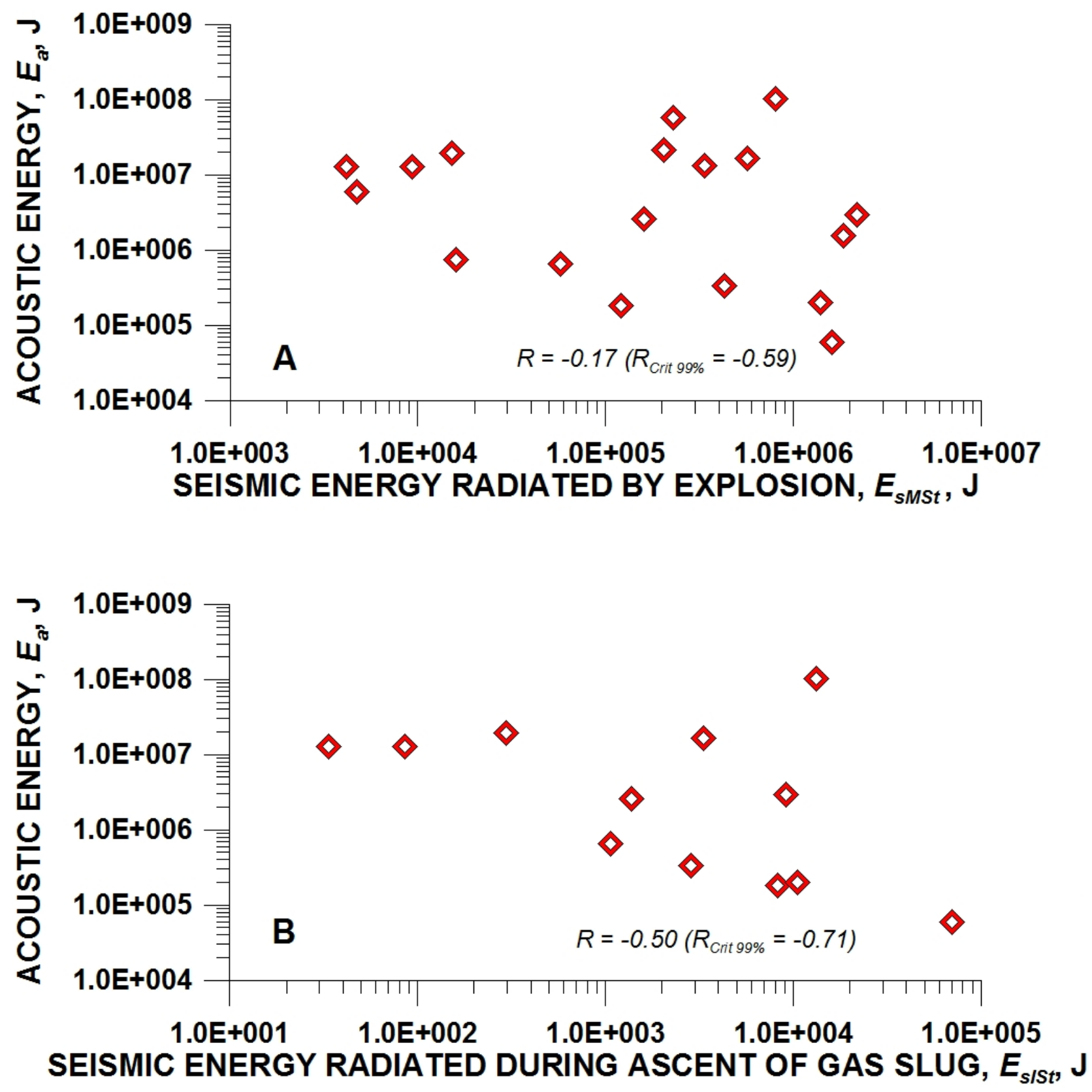


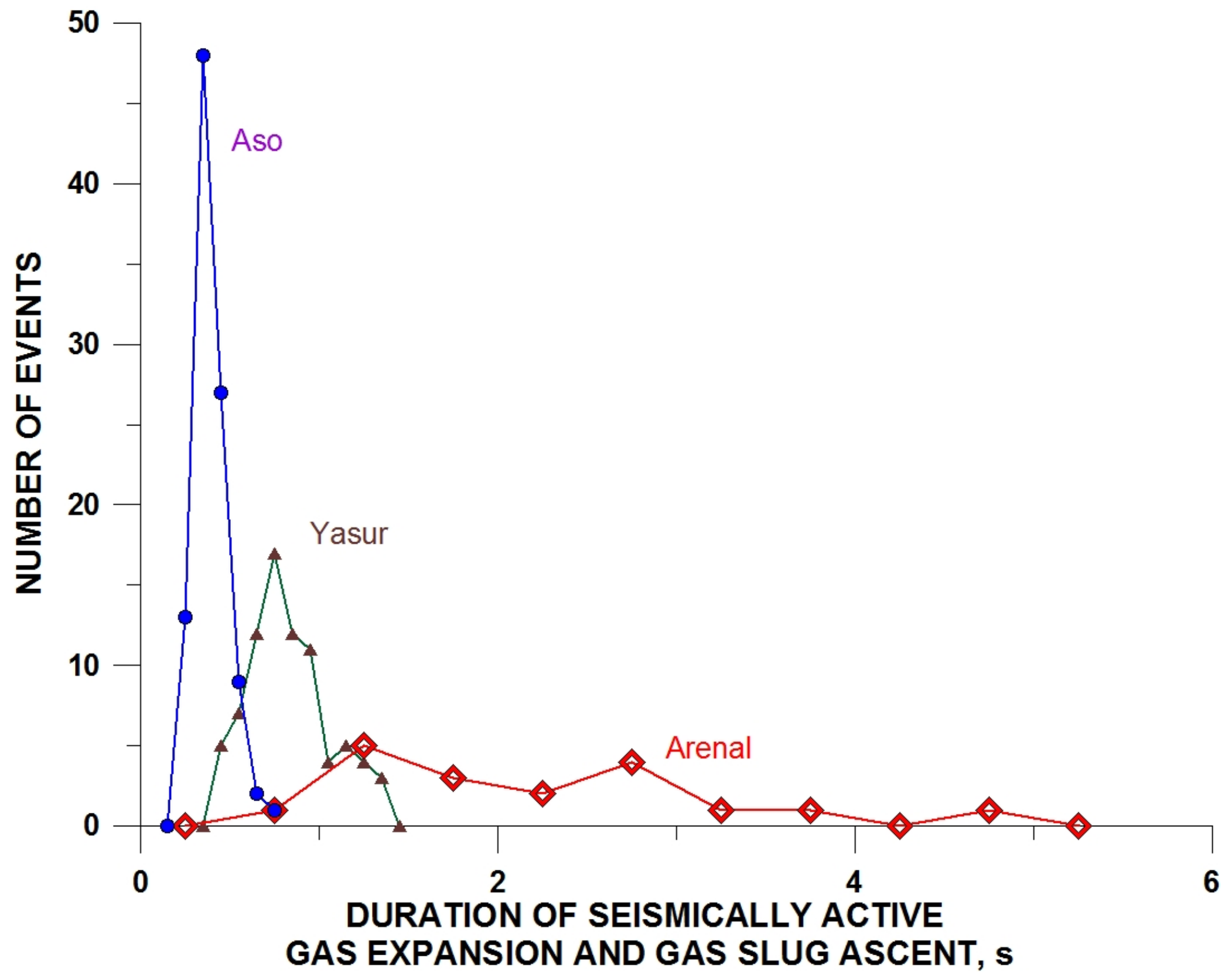




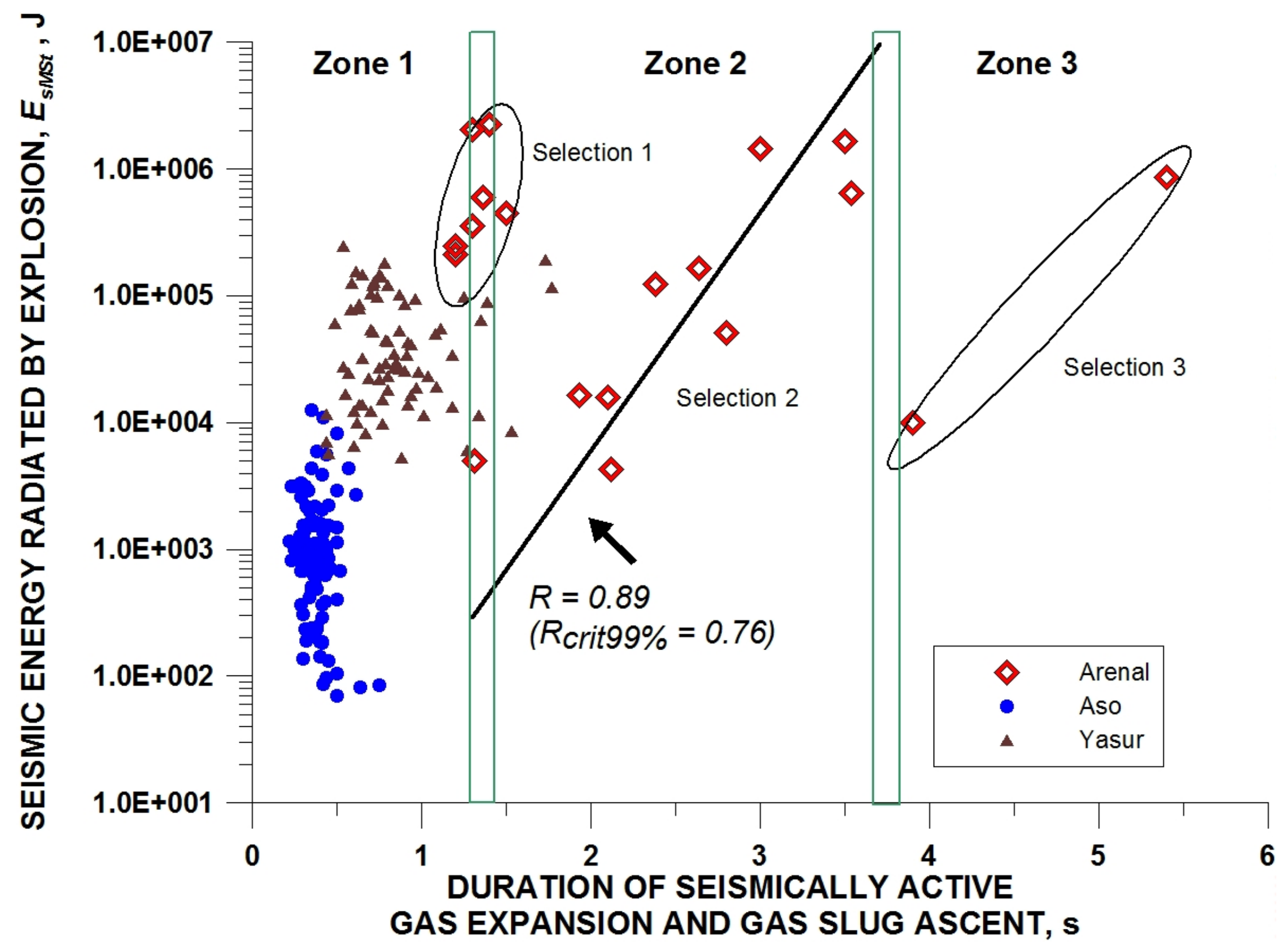




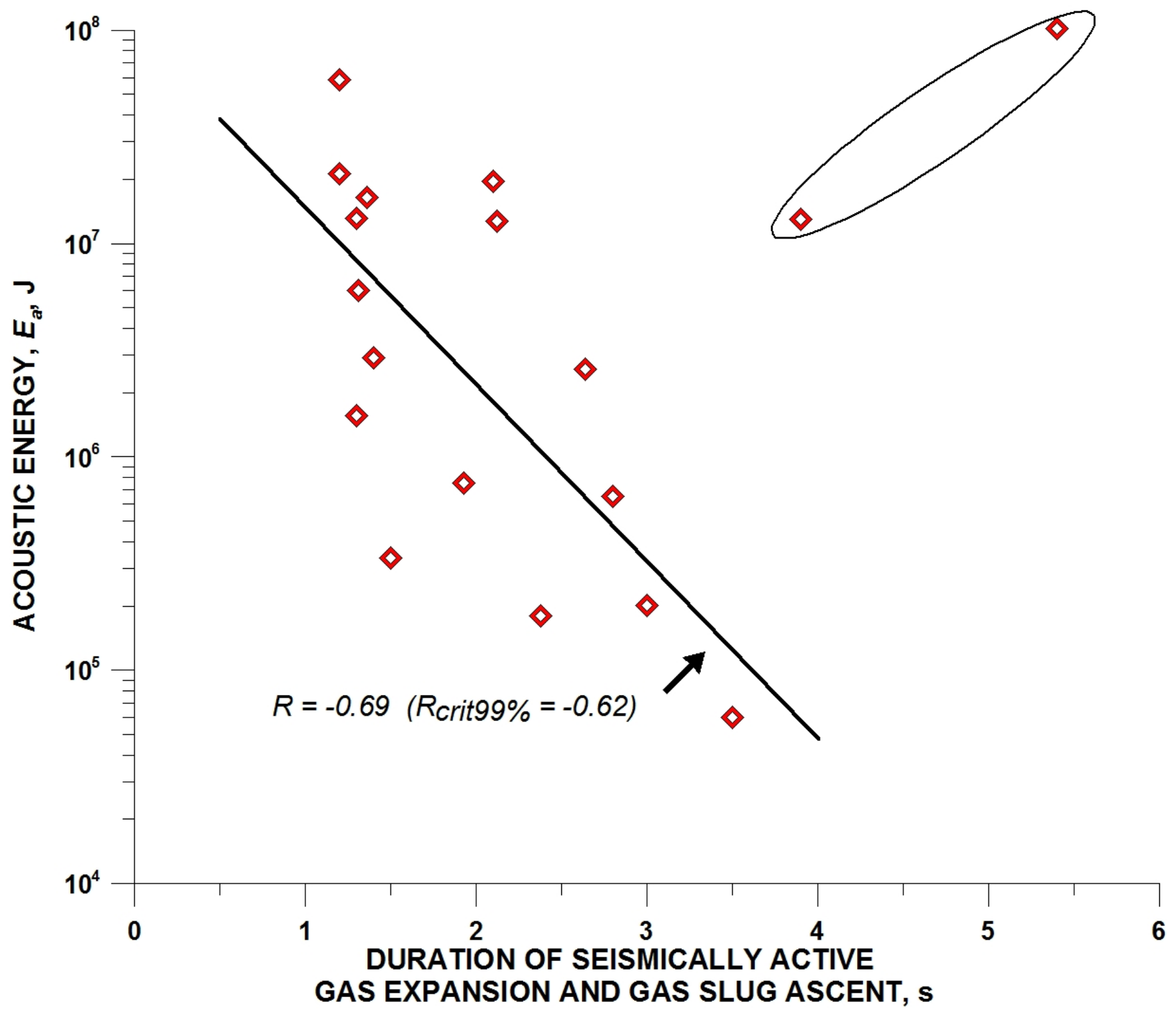


Table 1

Parameters used for calculation of the radiated seismic energy of two stages of explosions for three volcanoes

\begin{tabular}{|l|l|l|l|}
\hline Parameters & Arenal & Aso & Yasur \\
\hline Distance $r, \mathrm{~km}$ & 2.7 & 0.15 & 0.65 \\
\hline Density $\rho$, & 2500 & $2300^{2}$ & $1600^{4}$ \\
$\mathrm{~kg} / \mathrm{m}^{3}$ & & & \\
\hline $\begin{array}{l}\text { Group velocity } \\
c, \mathrm{~km} / \mathrm{s}\end{array}$ & $1.0^{l}$ & $1.7^{3}$ & $0.75^{5}$ \\
\hline Thickness $h, \mathrm{~m}$ & $450^{l}$ & & \\
\hline
\end{tabular}

Note. 1, Mora et al. (2006); 2, Komazawa et al., 1995; 3, Tsutsui et al. (2003); 4, Brothelande et al. (2016); 5, Perrier et al. (2012). See the meaning of symbols of parameters in the text. 